\title{
Mono- and Diamination of 4,6-Dichloropyrimidine, 2,6-Dichloropyrazine and 1,3-Dichloroisoquinoline with Adamantane-Containing Amines ${ }^{\dagger}$
}

\author{
Alisa D. Kharlamova ${ }^{1}$, Anton S. Abel ${ }^{1}{ }^{(1)}$, Alexei D. Averin ${ }^{1,2}$, Olga A. Maloshitskaya ${ }^{1}$, Vitaly A. Roznyatovskiy ${ }^{1}$, \\ Evgenii N. Savelyev $^{3}$, Boris S. Orlinson ${ }^{3}$, Ivan A. Novakov ${ }^{3}$ and Irina P. Beletskaya ${ }^{1,2, *(D)}$ \\ 1 Department of Chemistry, Lomonosov Moscow State University, Leninskie Gory, 1-3, 119991 Moscow, Russia; \\ alisa-harlamova@mail.ru (A.D.K.); antonabel@list.ru (A.S.A.); alexaveron@yandex.ru (A.D.A.); \\ maloshitskaya@mail.ru (O.A.M.); Vit.Rozn@nmr.chem.msu.su (V.A.R.) \\ 2 Frumkin Institute of Physical Chemistry and Electrochemistry, Russian Academy of Sciences, Leninsky Pr. 31, \\ 119071 Moscow, Russia \\ 3 Volgograd State Technical University, 28 Lenina prosp., 400131 Volgograd, Russia; \\ savelyev_en@vstu.ru (E.N.S.); orlinson@vstu.ru (B.S.O.); president@vstu.ru (I.A.N.) \\ * Correspondence: beletska@org.chem.msu.ru; Tel.: +7-495-939-11-39 \\ + Dedicated to Prof. Christian Bruneau for his outstanding contribution to catalysis.
}

check for updates

Citation: Kharlamova, A.D.; Abel, A.S.; Averin, A.D.; Maloshitskaya, O.A.; Roznyatovskiy, V.A.; Savelyev, E.N.; Orlinson, B.S.; Novakov, I.A.; Beletskaya, I.P. Mono- and Diamination of

4,6-Dichloropyrimidine,

2,6-Dichloropyrazine and 1,3-Dichloroisoquinoline with Adamantane-Containing Amines Molecules 2021, 26, 1910. https:// doi.org/10.3390/molecules26071910

Academic Editor: Maged Henary

Received: 23 February 2021

Accepted: 24 March 2021

Published: 29 March 2021

Publisher's Note: MDPI stays neutral with regard to jurisdictional claims in published maps and institutional affiliations.

Copyright: (c) 2021 by the authors. Licensee MDPI, Basel, Switzerland. This article is an open access article distributed under the terms and conditions of the Creative Commons Attribution (CC BY) license (https:// creativecommons.org/licenses/by/ $4.0 /)$.

\begin{abstract}
N-heteroaryl substituted adamantane-containing amines are of substantial interest for their perspective antiviral and psychotherapeutic activities. Chlorine atom at alpha-position of $\mathrm{N}$-heterocycles has been substituted by the amino group using convenient nucleophilic substitution reactions with a series of adamantylalkylamines. The prototropic equilibrium in these compounds was studied using NMR spectroscopy. The introduction of the second amino substituent in 4-amino6-chloropyrimidine, 2-amino-chloropyrazine, and 1-amino-3-chloroisoquinoline was achieved using $\operatorname{Pd}(0)$ catalysis.
\end{abstract}

Keywords: amines; adamantane; Pd catalysis; amination; pyrimidine; isoquinoline; pyrazine

\section{Introduction}

Amino substituted pyrimidines, pyrazines, and isoquinolines attract the researchers' interest due to their versatile biological activities stemming from the ability to form hydrogen bonds with various biomolecules, like nucleobases. Some derivatives of aminopyrimidine were found to act as inhibitors of various ferments: 1-phosphatidylinositol3-phosphate 5-kinase (FAB1B) (e.g., bacimethrin) [1-3], 1-acyl-sn-glycerol-3-phosphate acyltransferase (plsC) [4], [Pyruvate dehydrogenase (acetyl-transferring)] kinase isozyme 1 (PDHA1) (e.g., 6' $6^{\prime}\left(\left(6\right.\right.$-aminopyrimidin-4-yl)amino)-8' ${ }^{\prime}$-methyl-2' $H$-spiro[cyclohexane-1,3' imidazo[1,5-a]pyridine]-1 $1^{\prime}, 5^{\prime}$-dione) [5], and perform as multitarget RET (rearranged during transfection) inhibitors [6]. In particular, substituted 4,6-diaminopyrimidines are capable of blocking epidermal growth factor receptor (EGFR), what make them perspective for the lung cancer treatment [7]. The last five years have demonstrated that aminopyrazine derivatives constitute an important platform for the creation of the inhibitors of mutant isocitrate dehydrogenase 1 (IDH1) [8], mitogen-activated protein kinase-interacting kinases 1 and 2 (MNK1/2) [9], and serine/threonine kinase (BRAF) (e.g., 1-\{4-[6-(3,4,5Trimethoxyphenylamino)-pyrazin-2-yl]phenyl\}-3-phenyl urea) [10]. 2,6-Diaminopyrazine may serve as a backbone for the creating Nav1.7 antagonists [11], while substituted aminoisoquinolines (N-Methyl-3-(4-methylpiperazin-1-yl)isoquinolin-1-amine) bind to the receptor 5-HT3 [12].

Adamantane group helps to increase the lipophilicity of the molecules assuring their penetration through the biological membranes. Due to this ability adamantane derivatives demonstrate a wide range of biological activities [13]. The derivatives of 
adamantane-containing amines are known as the remedies against the Parkinson's disease (e.g., 1-adamantylamine) [14,15], they exhibit antitumor [16] and anti-HIV activities [16,17], and are widely renowned as influenza viral inhibitors [18]. An imposing array of the peptide derivatives containing adamantaneamines demonstrate a wide scope of biological activities [19]. The derivatives of the heterocyclic compounds bearing adamantaneamine moieties are of special interest as psychotropic agents (e.g., 2-(1-adamantyl)- $\mathrm{N}-\mathrm{H} \mathrm{H}$-indazol5 -ylacetamide) $[16,20,21]$, they act as $11 \beta-H S D 1$ (11 $\beta$-Hydroxysteroid dehydrogenase type 1) inhibitors [22-24], are able to elicit anti-nicotine antibodies [25], and show antiviral and antimicrobial activities [26].

In order to search for novel perspective biologically active compounds on the basis of amino substituted heterocycles a convenient method for the synthesis of ample series of such molecule bearing versatile groups is needed. Known approaches are often limited by harsh reaction conditions, thus diminishing the scope of available substrates, e.g., unsymmetrical 4,6-diaminopyrimidines were obtained using Pd-catalyzed reactions in low yields (5-27\%) [11]. Another study revealed the formation of many by-products in these processes and a strong demand for a fine adjustment of the reaction conditions [27]. The methods for 1,3-diaminoisoquinolines preparation are also limited. One of the best methods envisages $\alpha$-cyano-o-tolunitrile cyclization by the action of organolithium compounds [28]. They can be also synthesized by a two-step non-catalytic amination of 1,3-dichloroisoquinoline under harsh conditions, which provides quite moderate yields (up to 31\%) [12]. Fluorescent 1-morpholinoisoquinoline-3-amines were synthesized from 1-bromoisoquinoline-3-amine by heating with excess morpholine [29]. Recently, an original approach has been proposed for diamino derivatives of isoquinoline and pyrimidine, consisting of the catalytic cyclization of cyanamides and ynamides in the presence of gold complexes [30].

For the aforementioned reasons, the aim of this work is the elaboration of the approach to adamantane-containing 4,6-diaminopyrimidines, 2,6-diaminopyrazines, and 1,3-diaminoisoquinolines. Selective monoamination of the corresponding dichloroheteroarenes can be accomplished in high yields under catalyst-free conditions [31]. Non-catalytic introduction of the second amino group is seriously hindered by the electron donor effect of the first amino group. It is rational to use the Pd-catalyzed amination at the second step as it is depicted on Scheme 1. Earlier we demonstrated Pd-catalyzed diamination to be useful in one-step syntheses of symmetrical adamantane-containing diamino derivatives of pyridines [32], quinolines [33], and 1,10-phenanthrolines [34].
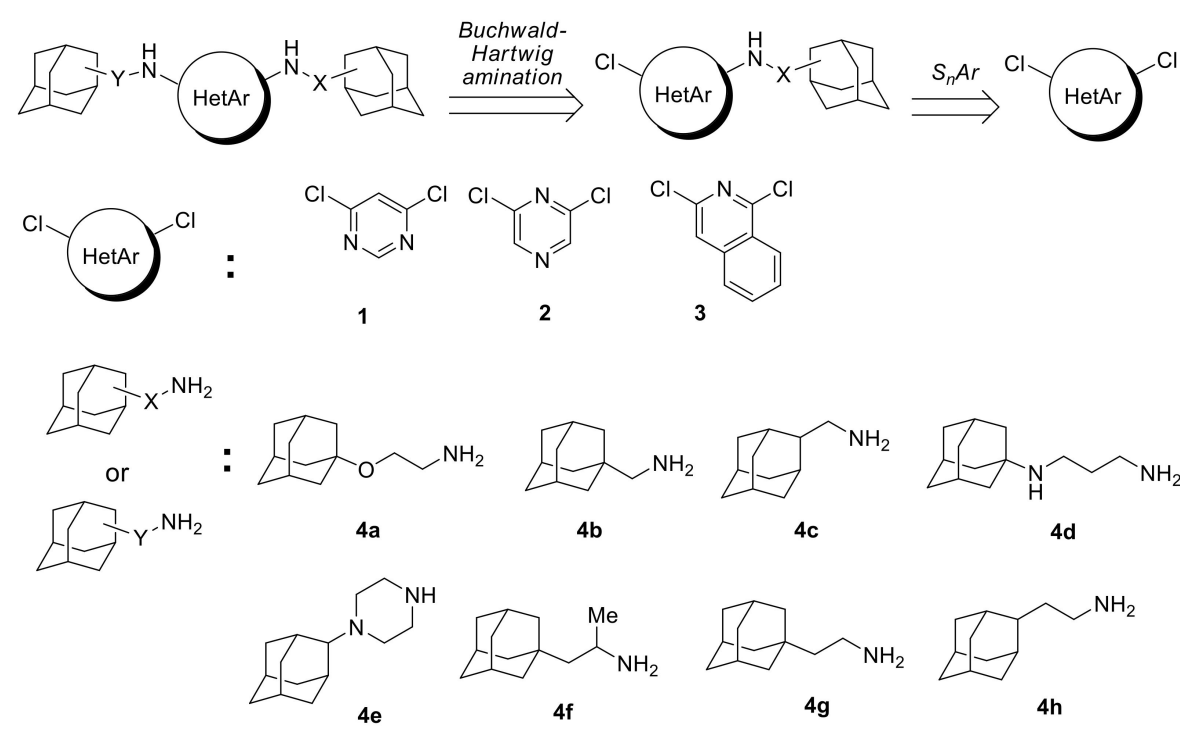

Scheme 1. A two-step approach to adamantane-containing diamino heteroarenes studied in this work. 


\section{Results and Discussion}

In the present study, we employed commercially available 3,6-dichloropyrimidine $\mathbf{1}$, 2,6-dichloropyrazine 2, and 1,3-dichloroisoquinoline 3 and a set of adamantane-containing amines differing by the substituents at the amino group (Scheme 1). At first, the catalystfree monoamination of 4,6-dichloropyrimidine 1 was undertaken, and the reactions were conducted under earlier optimized conditions (4 equiv. $\mathrm{K}_{2} \mathrm{CO}_{3}, \mathrm{DMF}, 140{ }^{\circ} \mathrm{C}$ ) (Scheme 2).

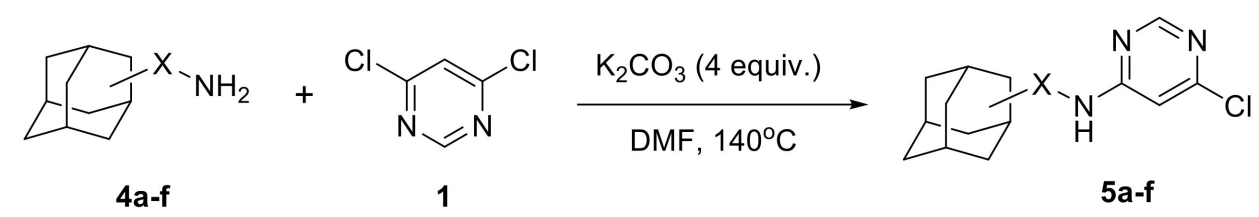<smiles>Clc1cc(NCCOC23CC4CC(CC(C4)C2)C3)ncn1</smiles>

5a, $99 \%$<smiles>Clc1cc(NCC23CC4CC(CC(C4)C2)C3)ncn1</smiles>

$5 \mathbf{b}, 65 \%$<smiles>Clc1cc(NCC2C3CC4CC(C3)CC2C4)ncn1</smiles><smiles></smiles>

$5 d, 60 \%$

$5 e, 55 \%$ (1 equiv. of 1 ) $75 \%$ (3 equiv. of 1 )<smiles>CC(CC12CC3CC(CC(C3)C1)C2)Nc1cc(Cl)ncn1</smiles>

$\mathbf{5 f}, 60 \%$<smiles>Clc1cc(NCCC23CC4CC(CC(C4)C2)C3)ncn1</smiles>

$5 g, 77 \%$

Scheme 2. Monoamination of 4,6-dichloropyrimidine with adamantane-containing amines.

The heteroarylation of a sterically unhindered amine 4 a proceeded smoothly and resulted in almost quantitative yield of the product $5 \mathbf{a}$. Amines $4 \mathbf{c}, \mathbf{g}$ with a closer position of the adamantane core to the amino group produced the target compounds in 76 and $77 \%$ yields, respectively. An increase in the steric hindrances in $4 \mathbf{b}, \mathbf{f}$ resulted in lower yields of the amination products $5 \mathbf{b}, \mathbf{f}(65$ and $60 \%)$. The diamine $4 \mathbf{d}$ reacted selectively and not surprisingly only the primary amino group participated in the heteroarylation affording compound $\mathbf{5 d}$ in $60 \%$ yield. Initially, $55 \%$ yield was obtained in the reaction with the secondary amine $5 \mathbf{e}$, but the result was improved (75\%) by taking 3 equiv. 4,6dichloropyrimidine.

Catalyst-free monoamination of 2,6-dichloropyrazine 2 and 1,3-dichloroisoquinoline 3 with a wide scope of adamantane-containing amines was studied earlier [31]. The known protocol [31] was employed for the synthesis of $\mathrm{N}$-(2-(1-adamantyloxy)ethyl)-6chloropyrazin-2-amine 6 and $N$-[2-(1-adamantyloxy)ethyl]-3-chloroisoquinolin-1-amine 7 in 82 and $89 \%$ yields (Scheme 3) for further studies of the substitution of the chlorine in these compounds. 
<smiles>Clc1cncc(NCCOC23CC4CC(CC(C4)C2)C3)n1</smiles>

$6,82 \%$

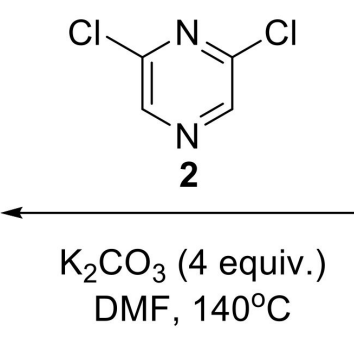

DMF, $140^{\circ} \mathrm{C}$

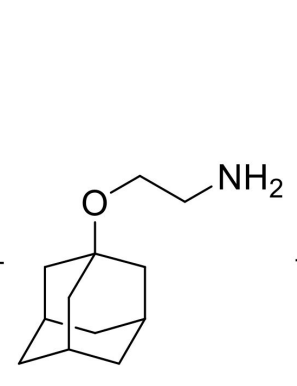

$4 a$

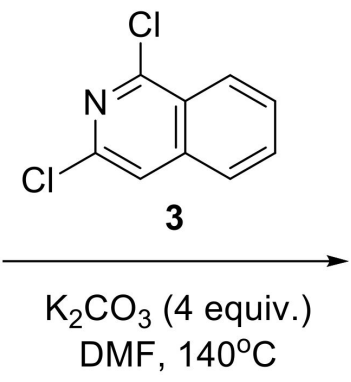

DMF, $140^{\circ} \mathrm{C}$<smiles>Clc1cc2ccccc2c(NCCOC23CC4CC(CC(C4)C2)C3)n1</smiles>

$7,89 \%$

Scheme 3. Monoamination of 2,6-dichloropyrazine and 1,3-dichloroisoquinoline.

The synthesis of adamantane-containing 4,6-diaminopyrimidines was studied using a model compound 5a with $\mathrm{Pd}(\mathrm{dba})_{2}$ as a precatalyst (Scheme 4, Table 1). Classical phosphine ligands, like BINAP (2,2'-bis(diphenylphosphino)-1,1'-binaphthyl) and DavePhos (2-Dicyclohexylphosphino-2'-(N,N-dimethylamino)biphenyl) [35], were studied, as well as Ph-JosiPhos and Cy-JosiPhos (CyPF- ${ }^{\mathrm{B}} \mathrm{Bu}$ ), which were shown to be efficient in the amination of halosubstituted heterocycles [36,37], were also tested. Other donor phosphine ligands with bulky substituents (SPhos, XPhos, RuPhos BrettPhos) were not studied in this reaction as they earlier had been shown to be much less efficient in the heteroarylation of adamantane-containing amines with 2-bromopyridines [38]. The reaction of $\mathbf{5 a}$ with 1 equiv. of amine $4 \mathbf{a}$ in the presence of $\operatorname{Pd}(0) / \operatorname{BINAP}$ (Table 1, entry 1 ) produced a complex mixture of compounds. The ${ }^{1} \mathrm{H}$ NMR signals in the range of 4.0-4.5 ppm (attributed to the signals of $\mathrm{CH}_{2} \mathrm{~N}(\mathrm{HetAr})_{2}$ groups) suggest the formation of various products of $\mathrm{N}, \mathrm{N}$-diheteroarylation including oligomeric ones. MALDI-TOF mass spectra revealed the presence of the oligomers comprising 2-3 pyrimidine units combined with 3 or 4 amine fragments which could not be separated by column chromatography (e.g., (4a) ${ }_{3} \mathbf{H e t}_{2}$, $[\mathrm{M}+\mathrm{H}]^{+} 738.48$ and $(\mathbf{4 a})_{4} \mathbf{H e t}_{3},[\mathrm{M}+\mathrm{H}]^{+}$1009.59, Scheme 4). N,N-diheteroarylation was observed to be typical in the amination of 2-halosubstituted 6-membered heterocycles (pyridine and quinoline) $[32,33,39,40]$.

Table 1. Pd-catalyzed amination of 4-amino-6-chloropyrimidine 5a.

\begin{tabular}{|c|c|c|c|c|c|}
\hline Entry & Amine & $\begin{array}{l}\text { Equiv. of } \\
\text { Amine }\end{array}$ & Ligand & $\begin{array}{c}\mathrm{Pd}(\mathrm{dba})_{2} / \mathrm{L} \\
\mathrm{mol} \%\end{array}$ & Product, Yield, \% \\
\hline 1 & $4 a$ & 1 & BINAP & $4 / 4.5$ & $8 \mathbf{a}$, oligomers $^{1}$ \\
\hline 2 & $4 a$ & 2 & Cy-JosiPhos & $2 / 2.5$ & $8 a$, oligomers $^{1}$ \\
\hline 3 & $4 a$ & 2 & DavePhos & $4 / 4.5$ & $8 \mathbf{a}$, oligomers $^{1}$ \\
\hline 4 & $4 a$ & 2 & Ph-JosiPhos & $4 / 4.5$ & $8 a$, oligomers $^{1}$ \\
\hline 5 & $4 a$ & 4 & DavePhos & $4 / 4.5$ & $8 a, 60$ \\
\hline 6 & $4 a$ & 4 & BINAP & $8 / 9$ & $8 a, 61$ \\
\hline 7 & $4 b$ & 4 & DavePhos & $4 / 4.5$ & $8 b, 40$ \\
\hline 8 & $4 \mathrm{f}$ & 4 & DavePhos & $4 / 4.5$ & $8 f, 46$ \\
\hline
\end{tabular}

${ }^{1}$ Side products were observed in ${ }^{1} \mathrm{H}$ NMR spectra of the reaction mixtures and confirmed by MALDI-TOF mass spectroscopy.

The use of bulky ligands (DavePhos, Ph-JosiPhos, and Cy-JosiPhos) did not lead to an increase in the product yield even in the presence of 2 equiv. amine (entries 2-4). The use of 4 equiv. amine allowed to obtain the target product in $60 \%$ yield (entry 5). The use of BINAP in this case gave the same yield, but with higher catalyst loading (entry 6). The reaction of more sterically hindered amines $4 \mathbf{b}$ and $4 \mathbf{f}$ with $5 \mathbf{a}$ in the presence of $\mathrm{Pd}(0) /$ DavePhos catalyst led to the formation of the unsymmetrical products $8 \mathbf{b}(40 \%)$ and $\mathbf{8 f}(46 \%)$, respectively (entries 7,8$)$. $N, N$-diheteroarylation was also 
observed in all cases; however, corresponding products were always obtained as mixtures and could not be isolated in pure state.

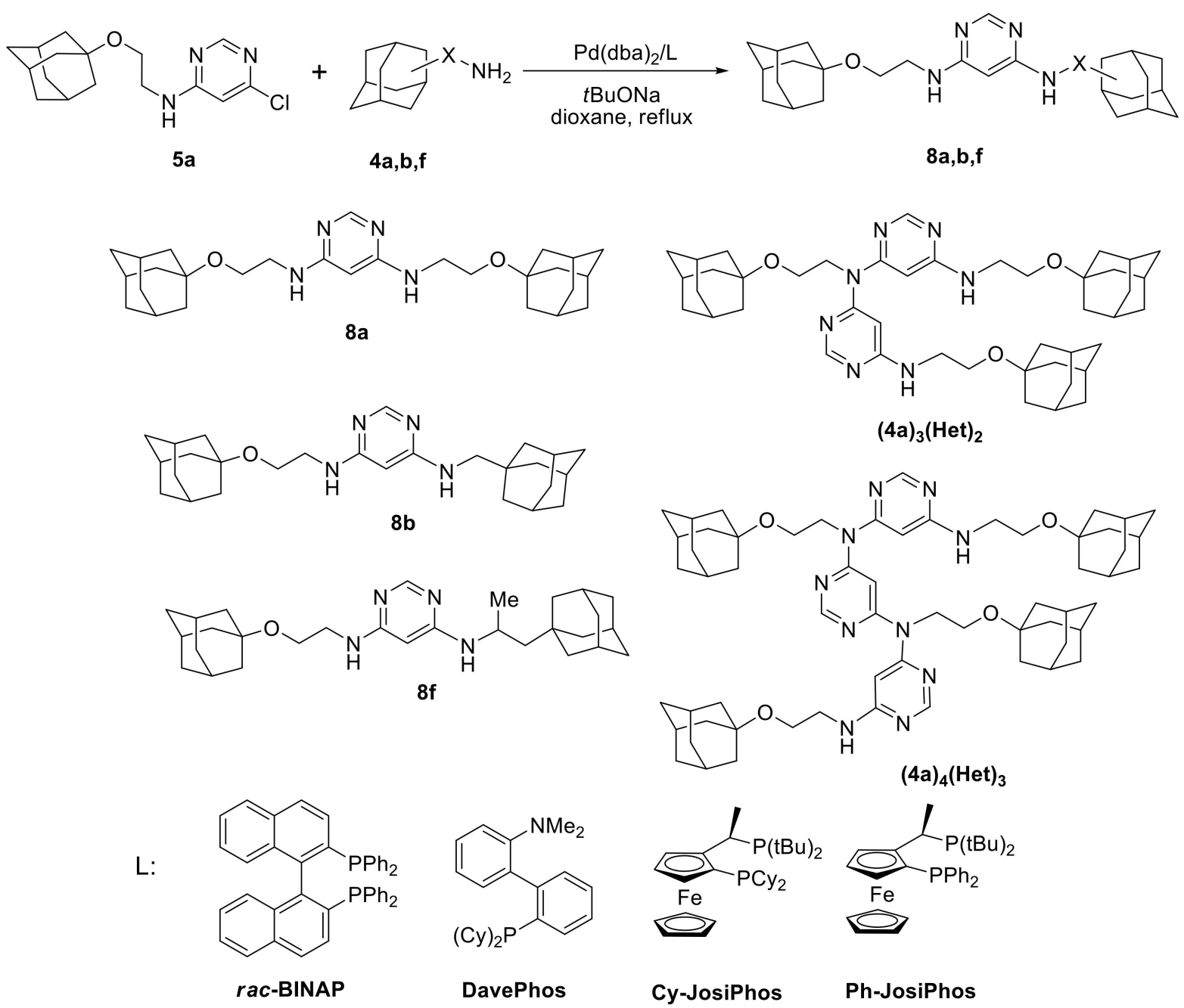

Scheme 4. Synthesis of adamantane-containing 4,6-diaminopyrimidines.

Such propensity for the diheteroarylation can be explained by the fact that 4-amino6-chloropyrimidines exist as two tautomers A and $\mathbf{B}$ in equilibrium (Scheme 5). It may increase the NH-Het proton mobility and result in a faster $N, N$-diheteroarylation. Tautomeric equilibria of amine-imine type are natural for 2-aminoheterocycles and have been under investigation as it is a common form of isomerism for nucleobases. This phenomenon governs the ability of the heterocycles to form hydrogen bonds [41] and participate in redox processes [42].<smiles>[X]C12CC3CC(CC(C3)C1)C2</smiles>

A

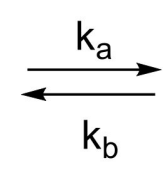

$\mathrm{k}_{\mathrm{b}}$<smiles>[X]C12CC3CC(CC(C3)C1)C2</smiles>

B

Scheme 5. Prototropic equilibrium in 4-amino-6-chloropyrimidines. 
In the case of the pyrimidine derivatives 5 , the tautomers were observed in the ${ }^{1} \mathrm{H}$ $\mathrm{NMR}$ spectra. Line broadening was notable for $\mathrm{NH}$, aliphatic $\mathrm{CHN}$ protons, as well for the protons of the heterocyclic ring. To get a deeper insight in the phenomenon, the influence of the steric hindrances at the amino group on the tautomerism was studied for the compounds $\mathbf{5 b}, \mathbf{5 c}, \mathbf{5 f}$, and $\mathbf{5 g}$. NMR spectra of these compounds were registered in $\mathrm{CDCl}_{3}$ at different temperatures in the range $223-323 \mathrm{~K}$ to get activation energy characteristics presented in Table 2.

Table 2. The activation energy characteristics of prototropic equlibrium of $5 \mathbf{b}, \mathbf{c}, \mathbf{f}, \mathbf{g}$.

\begin{tabular}{|c|c|c|c|c|c|c|c|}
\hline Entry & Compound & $X$ & Reaction & $\mathbf{K}_{273}$ & $\begin{array}{c}\Delta \mathbf{H}^{\neq}, \\
\mathrm{kcal} / \mathrm{mol}\end{array}$ & $\begin{array}{c}\Delta \mathbf{S}^{\neq}, \\
\mathrm{cal} / \mathrm{mol} \times \mathrm{K}\end{array}$ & $\begin{array}{c}\Delta \mathrm{G}^{\neq}(273 \mathrm{~K}) \prime \\
\mathrm{kcal} / \mathrm{mol}\end{array}$ \\
\hline 1 & $5 g$ & 1- $\mathrm{CH}_{2} \mathrm{CH}_{2}$ & $\mathbf{A} \rightarrow \mathbf{B}$ & \multirow{2}{*}{0.45} & 17.84 & 13.58 & 14.24 \\
\hline 2 & $5 \mathrm{~g}$ & $1-\mathrm{CH}_{2} \mathrm{CH}_{2}$ & $\mathbf{B} \rightarrow \mathbf{A}$ & & 16.89 & 12.65 & 13.81 \\
\hline 3 & $5 b$ & $1-\mathrm{CH}_{2}$ & $\mathbf{A} \rightarrow \mathbf{B}$ & \multirow{2}{*}{0.495} & 19.30 & 17.51 & 14.67 \\
\hline 4 & $5 b$ & $1-\mathrm{CH}_{2}$ & $\mathbf{B} \rightarrow \mathbf{A}$ & & 18.46 & 15.81 & 14.29 \\
\hline 5 & $5 c$ & $2-\mathrm{CH}_{2}$ & $\mathbf{A} \rightarrow \mathbf{B}$ & \multirow{2}{*}{0.54} & 16.31 & 7.38 & 14.48 \\
\hline 6 & $5 c$ & $2-\mathrm{CH}_{2}$ & $\mathbf{B} \rightarrow \mathbf{A}$ & & 15.42 & 5.30 & 14.15 \\
\hline 7 & $5 f$ & $1-\mathrm{CH}_{2} \mathrm{CH}\left(\mathrm{CH}_{3}\right)$ & $\mathbf{A} \rightarrow \mathbf{B}$ & \multirow{2}{*}{0.575} & 17.36 & 11.90 & 14.26 \\
\hline 8 & $5 f$ & $1-\mathrm{CH}_{2} \mathrm{CH}\left(\mathrm{CH}_{3}\right)$ & $\mathbf{B} \rightarrow \mathbf{A}$ & & 16.69 & 10.59 & 13.96 \\
\hline
\end{tabular}

The spectra were fitted using WinDNMR software and tautomers ratio was calculated (see Supplementary Materials). Reaction rate constants sum $\left(k=k_{a}+k_{b}\right)$ and equilibrium constant $\left(\mathrm{K}=\mathrm{k}_{\mathrm{a}} / \mathrm{k}_{\mathrm{b}}=[\mathrm{B}] /[\mathrm{A}]\right)$ were determined for each temperature. The activation energy characteristics $\left(\Delta \mathrm{H}^{\neq}\right.$and $\left.\Delta \mathrm{S}^{\neq}\right)$were calculated from the experiments using Eyring equation and are given in Table 2. While enthalpy and entropy of the activation of the processes differ substantially, the Gibbs energy does not show significant dependence on the structure of the compounds. With elevating the temperature, an increase in the imine ratio is observed and reaches $40 \%$ at $351-325 \mathrm{~K}$. This could explain an easy formation of the palladium amide I complex from the imine form and, consequently, the tendency of the monoarylated product to participate in the second arylation step forming the $N, N$-diaryl derivative (Scheme 6). As it is known, the deprotonation of the palladium amine complex with its transformation into the amide complex is a rate-determining step of the catalytic cycle, and, in the present case, formation of the amide complex $\mathbf{I}$ is faster than amide complex II because of equilibrium between $\mathbf{A}$ and $\mathbf{B}$ forms.

The amination of 2-amino-6-chloropyrazine $\mathbf{6}$ (Scheme 7) using 1 equiv. of $4 \mathbf{a}$ also led to a complex mixture of oligomers (Table 3, entries 1,2), preventing the isolation of the target compound $9 \mathbf{a}$ in a pure state. The application of 2 equiv. amine in the presence of $\operatorname{Pd}(0) / C y$-JosiPhos catalytic system afforded $9 a$ in $30 \%$ yield (entry 3 ) and the use of 4 equiv. amine with Ph-JosiPhos allowed the isolation of $9 a$ in $90 \%$ yield (entry 4). Under analogous conditions, $\mathbf{9 b}, \mathbf{9 g}$, and $9 \mathrm{~h}$ were synthesized in moderate yields $36-48 \%$ (entries $5,7,8$ ). Indeed, the target products were obtained in much better yields in the reaction mixtures, but the losses during the separation from the oligomeric products badly decreased the isolated yields. Compound $9 \mathrm{f}$ could not be isolated in a pure state due to such problem; its yield was estimated as $47 \%$ by ${ }^{1} \mathrm{H}$ NMR spectrum (entry 6 ). 


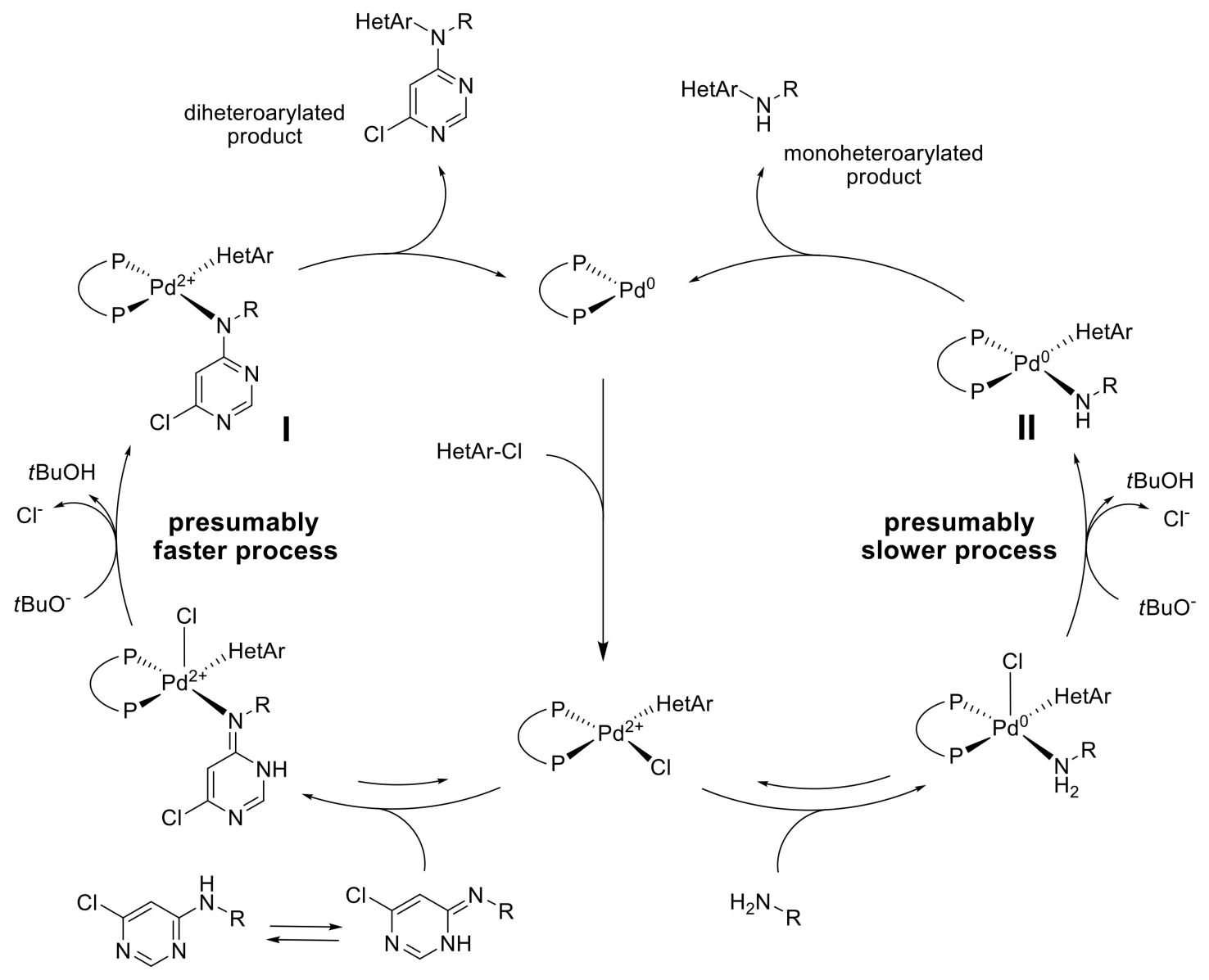

Scheme 6. Proposed mechanism of the formation of mono- and di-heteroarylated products.
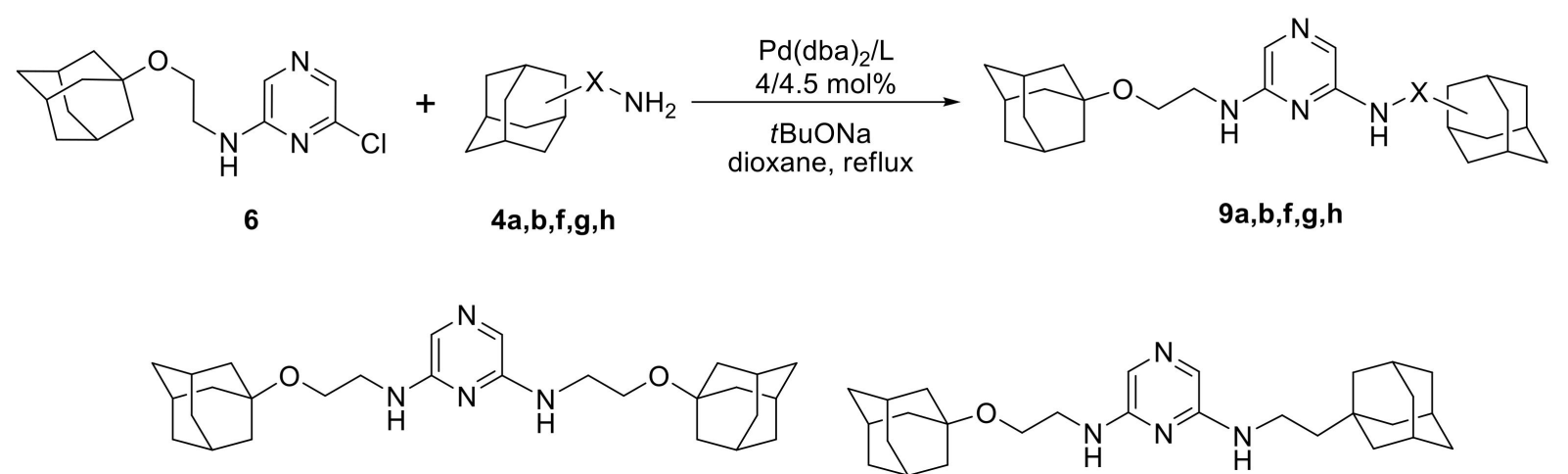

9 a<smiles>c1ncc(NCCC23CC4CC(CC(C4)C2)C3)nc1NCCOC12CC3CC(CC(C3)C1)C2</smiles><smiles>c1ncc(NCCC23CC4CC(CC(C4)C2)C3)nc1NCCOC12CC3CC(CC(C3)C1)C2</smiles>

$9 b$<smiles>c1ncc(NCCC2C3CC4CC(C3)CC2C4)nc1NCCOC12CC3CC(CC(C3)C1)C2</smiles><smiles>CC(CC12CC3CC(CC(C3)C1)C2)Nc1cncc(NCCOC23CC4CC(CC(C4)C2)C3)n1</smiles>

Scheme 7. Synthesis of adamantane-containing 2,6-diaminopyrazines. 
Table 3. Pd-catalyzed amination of 2-amino-6-chloropyrazine 6.

\begin{tabular}{ccccc}
\hline Entry & Amine & Equiv. of Amine & Ligand & Product, Yield (\%) \\
\hline 1 & $\mathbf{4 a}$ & 1 & BINAP & $\mathbf{9 a}$, oligomers ${ }^{\text {a }}$ \\
2 & $\mathbf{4 a}$ & 1 & DavePhos & $\mathbf{9 a}$ oligomers \\
3 & $\mathbf{4 a}$ & 2 & Cy-JosiPhos & $\mathbf{9 a}, 30$ \\
4 & $\mathbf{4 a}$ & 4 & Ph-JosiPhos & $\mathbf{9 a}, 90$ \\
5 & $\mathbf{4 b}$ & 4 & Ph-JosiPhos & $\mathbf{9 b}, 42$ \\
6 & $\mathbf{4}$ & 4 & Ph-JosiPhos & $\mathbf{9 f},(47) \mathrm{b}$ \\
7 & $\mathbf{4}$ & 4 & Ph-JosiPhos & $\mathbf{9 g}, 48$ \\
8 & $\mathbf{4}$ & Ph-JosiPhos & $\mathbf{9 h}, 36$ \\
\hline
\end{tabular}

a Side products were observed in ${ }^{1} \mathrm{H}$ NMR spectra of the reaction mixtures and confirmed by MALDI-TOF mass spectroscopy $(\mathbf{( 4 a )})_{3}$ Het $_{2},[\mathrm{M}+\mathrm{H}]^{+} 738.48$ and $(\mathbf{4 a})_{4}$ Het $_{3},[\mathrm{M}+\mathrm{H}]^{+}$1009.61). ${ }^{\mathrm{b}}$ Yield was determined by ${ }^{1} \mathrm{H}$ NMR spectrum of the reaction mixture.

The amination of 2-amino-3-chloroisoquinoline $\mathbf{7}$ (Scheme 8) is also complicated by the formation of oligomers; however, in this case, it is somewhat less prominent, presumably due to more steric hindrances at the $\mathrm{NH}$ group. The application of 2 equiv. amine in the presence of $\mathrm{Pd}(0) / \mathrm{Cy}$-JosiPhos and $\mathrm{Pd}(0) /$ DavePhos catalytic systems gave only a mixture of oligomers (Table 4, entries 1,2). In the first case, the formation of the product $\mathbf{1 1}$ of $\mathrm{C}-\mathrm{Cl}$ bond reduction was observed (entry 1 ). The use of 4 equiv. amine in the presence of $\mathrm{Pd}(0) /$ DavePhos afforded the desired compound 10a in $77 \%$ yield (entry 3 ). The test of the BINAP ligand, even at greater catalyst loading, did not lead to an increase in the product yield (entry 4). Under optimized conditions, 1,3-diaminoisoquinolines 10b, 10f and 10g were obtained in $43-67 \%$ yields (entries $5-7$ ).

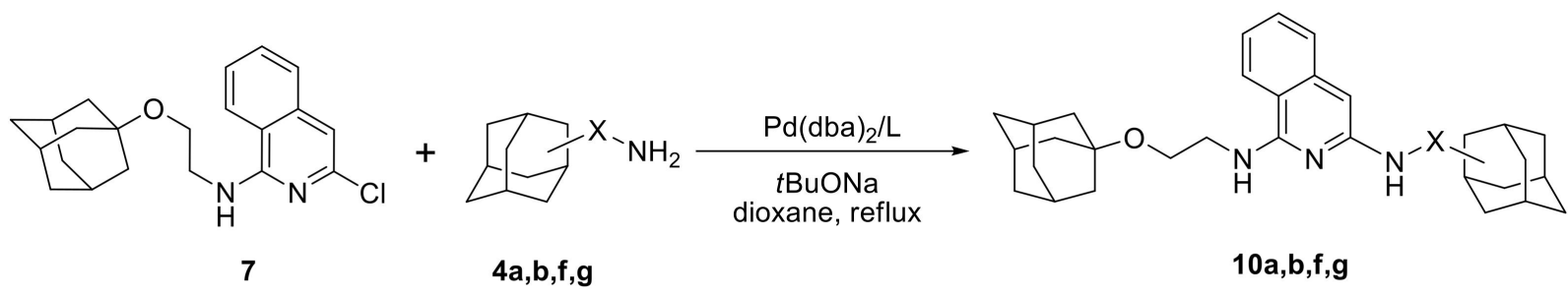<smiles></smiles><smiles>CC(CC12CC3CC(CC(C3)C1)C2)Nc1cc2ccccc2c(NCCOC23CC4CC(CC(C4)C2)C3)n1</smiles>

Scheme 8. Synthesis of adamantane-containing 1,3-diaminoisoquinolines. 
Table 4. Pd-catalyzed amination of 1-amino-3-chloroisoquinoline 7.

\begin{tabular}{|c|c|c|c|c|c|}
\hline Entry & Amine & $\begin{array}{l}\text { Equiv. of } \\
\text { Amine }\end{array}$ & Ligand & $\begin{array}{c}\mathrm{Pd}(\mathrm{dba})_{2} / \mathrm{L} \\
\mathrm{mol} \%\end{array}$ & $\begin{array}{l}\text { Product, } \\
\text { Yield }\end{array}$ \\
\hline 1 & $4 a$ & 2 & Cy-JosiPhos & $4 / 4.5$ & $10 a, 11^{a}$ \\
\hline 2 & $4 a$ & 2 & DavePhos & $4 / 4.5$ & $\begin{array}{c}10 a, \\
\text { oligomers a }\end{array}$ \\
\hline 3 & $4 a$ & 4 & DavePhos & $4 / 4.5$ & $10 a, 77 \%$ \\
\hline 4 & $4 a$ & 4 & BINAP & $8 / 9$ & $10 a, 76 \%$ \\
\hline 5 & $4 b$ & 4 & DavePhos & $4 / 4.5$ & $10 \mathrm{~b}, 62 \%$ \\
\hline 6 & $4 f$ & 4 & DavePhos & $4 / 4.5$ & $10 f, 67 \%$ \\
\hline 7 & $4 \mathrm{~g}$ & 4 & DavePhos & $4 / 4.5$ & $10 \mathrm{~g}, 43 \%$ \\
\hline
\end{tabular}

\section{Materials and Methods}

NMR spectra were registered using a Bruker Avance 400 spectrometer (Bruker Daltonics, Germany), MALDI-TOF spectra were obtained with a Bruker Autoflex II spectrometer (Bruker Daltonics, Germany) using 1,8,9-trihydroxyanthracene as a matrix and polyethylene glycols (PEGs) as internal standards. Dichloropyrimidine, dichloropyrazine, dichloroisoquinoline, BINAP, DavePhos and JosiPhos ligands, sodium tert-butoxide, and potassium carbonate were purchased from Aldrich (Daltonics, Germany) and Acros (Morris Plains, NJ, USA) and used without further purification. Amines $4 \mathbf{a}$ and $\mathbf{4 b}$ were prepared according to reported procedures of References [43,44], respectively. Amines $4 \mathbf{c}$ and $\mathbf{4 e ,}, \mathbf{g}, \mathbf{h}$, were obtained according to a method described in Reference [45], amines $\mathbf{4} \mathbf{d}$ and $\mathbf{4 f}$ were obtained according to methods described in References [39,46]. $\mathrm{Pd}(\mathrm{dba})_{2}$ was synthesized from $\mathrm{PdCl}_{2}$ according to a known procedure [47]. Dioxane was distilled over $\mathrm{NaOH}$ followed by the distillation over sodium under argon. Dimethylformamide was distilled over sodium hydride under reduced pressure. Dichloromethane and methanol were used freshly distilled.

\subsection{N-(Heteroaryl)-Substituted Adamantane-Containing Amines 5-7 (General Procedure)}

A corresponding chlorosubstituted heteroarene $(0.5-2 \mathrm{mmol})$, finely powdered anhydrous $\mathrm{K}_{2} \mathrm{CO}_{3}(1.25-8 \mathrm{mmol})$, DMF (1-4 mL), and a corresponding adamantane-containing amine $4(0.5-2 \mathrm{mmol})$ were placed into a glass vial equipped with a magnetic stirrer and screw tap, and the reaction mixture was stirred for $24 \mathrm{~h}$ at $140^{\circ} \mathrm{C}$. On the reaction completion, the mixture was cooled to room temperature, dichloromethane $(5 \mathrm{~mL})$ was added, an inorganic precipitate was filtered off and additionally washed with dichloromethane $(5 \mathrm{~mL})$, the combined organic filtrates were concentrated in vacuo, and the residues were analyzed by NMR spectroscopy. The products were purified by chromatography on silica gel, using the following sequence of eluents: hexanes- $\mathrm{CH}_{2} \mathrm{Cl}_{2}$ (4:1-1:4), $\mathrm{CH}_{2} \mathrm{Cl}_{2}, \mathrm{CH}_{2} \mathrm{Cl}_{2}-\mathrm{MeOH}$ (200:1-50:1).

$\mathrm{N}$-[2-(1-Adamantyloxy)ethyl]-6-chloropyrimidin-4-amine (5a). Obtained from dichloropyrimidine $1(298 \mathrm{mg})$, amine $4 \mathrm{a}(390 \mathrm{mg})$ in the presence of $\mathrm{K}_{2} \mathrm{CO}_{3}(1.12 \mathrm{~g})$ in $4 \mathrm{~mL}$ of DMF. Yield $608 \mathrm{mg}(99 \%)$, white amorphous powder, m.p. $136-137^{\circ} \mathrm{C} .{ }^{1} \mathrm{H}-\mathrm{NMR}\left(\mathrm{CDCl}_{3}\right)$ $\delta 1.55-1.64(\mathrm{~m}, 6 \mathrm{H}, \mathrm{Ad}), 1.69-1.70(\mathrm{~m}, 6 \mathrm{H}, \mathrm{Ad}), 2.10(\mathrm{~s}, 3 \mathrm{H}, \mathrm{Ad}), 3.41$ (br. s, $2 \mathrm{H}, \mathrm{CH}_{2}(\mathrm{NH})$ ), 3.55 (br.t, $\left.2 \mathrm{H},{ }^{3} J_{\text {obs }}=4.9 \mathrm{~Hz}, \mathrm{CH} 2(\mathrm{O})\right), 5.73$ (br. s., $\left.1 \mathrm{H}, \mathrm{NH}\right), 6.35$ (s, $\left.1 \mathrm{H}, \mathrm{H} 5\right), 8.29$ (s, $1 \mathrm{H}$, H2). ${ }^{13} \mathrm{C}-\mathrm{NMR}\left(\mathrm{CDCl}_{3}\right) \delta 30.2(3 \mathrm{C}, \mathrm{Ad}), 36.1(3 \mathrm{C}, \mathrm{Ad}), 41.2(3 \mathrm{C}, \mathrm{Ad}), 41.6\left(1 \mathrm{C}, \mathrm{CH}_{2}(\mathrm{NH})\right)$, 57.9 (1C, $\left.\mathrm{CH}_{2}(\mathrm{O})\right), 72.4\left(1 \mathrm{C}, \mathrm{C}_{\text {quat }}(\mathrm{O})\right), 103.8$ (1C, C5), 158.1 (2C, C2, C4), 163.1 (1C, C6). HRMS (MALDI-TOF): $m / z$ [M + H] ${ }^{+}$calcd for $\mathrm{C}_{16} \mathrm{H}_{23} \mathrm{ClN}_{3} \mathrm{O}$ : 308.1524; observed: 308.1481 .

$\mathrm{N}$-[(1-Adamantyl)methyl]-6-chloropyrimidin-4-amine (5b). Obtained from dichloropyrimidine $(75 \mathrm{mg})$, amine $5 \mathbf{b}(83 \mathrm{mg})$ in the presence of $\mathrm{K}_{2} \mathrm{CO}_{3}(276 \mathrm{mg})$ in $1 \mathrm{~mL}$ of DMF. Yield $90 \mathrm{mg}(65 \%)$, yellowish viscous oil. ${ }^{1} \mathrm{H}-\mathrm{NMR}\left(\mathrm{CDCl}_{3}\right) \delta 1.44-1.75(\mathrm{~m}, 12 \mathrm{H}, \mathrm{Ad})$, 1.99 (s, 3H, Ad), 2.92 (br. s., 2H, $\mathrm{CH}_{2}(\mathrm{NH})$ ), 5.84 (br. s., $1 \mathrm{H}, \mathrm{NH}$ ), 6.33 (s, 1H, H5), 8.28 $(\mathrm{s}, 1 \mathrm{H}, \mathrm{H} 2) .{ }^{13} \mathrm{C}-\mathrm{NMR}\left(\mathrm{CDCl}_{3}\right) \delta 28.1$ (3C, Ad), 34.1 (1C, $\left.\mathrm{C}_{\text {quat }}\right), 36.8$ (3C, Ad), 40.3 (3C, Ad), 
53.5 (1C, $\left.\mathrm{CH}_{2}(\mathrm{NH})\right), 100.3$ (1C, C5), 158.2 (2C, C2, C4), 159.1 (1C, C4), 163.9 (1C, C6). HRMS (MALDI-TOF): $m / z[\mathrm{M}+\mathrm{H}]^{+}$calcd for $\mathrm{C}_{15} \mathrm{H}_{21} \mathrm{ClN}_{3}$ : 278.1419; observed: 278.1399.

$\mathrm{N}$-[(2-Adamantyl)methyl]-6-chloropyrimidin-4-amine (5c). Obtained from $\mathrm{K}_{2} \mathrm{CO}_{3}$ (276 mg) in $1 \mathrm{~mL}$ of DMF. Yield $105 \mathrm{mg}(76 \%)$, yellowish viscous oil. ${ }^{1} \mathrm{H}-\mathrm{NMR}\left(\mathrm{CDCl}_{3}\right)$ $\delta 1.55\left(\mathrm{~d}, 2 \mathrm{H},{ }^{3} \mathrm{~J}=11.8 \mathrm{~Hz}, \mathrm{Ad}\right), 1.67-1.71(\mathrm{~m}, 4 \mathrm{H}, \mathrm{Ad}), 1.77-1.90$ (m, 9H, Ad), 3.35 (br. s, $\left.2 \mathrm{H}, \mathrm{CH}_{2}(\mathrm{NH})\right), 5.84$ (br. s., $\left.1 \mathrm{H}, \mathrm{NH}\right), 6.33$ (s, $\left.1 \mathrm{H}, \mathrm{H} 5\right), 8.28$ (s, $\left.1 \mathrm{H}, \mathrm{H} 2\right) .{ }^{13} \mathrm{C}-\mathrm{NMR}\left(\mathrm{CDCl}_{3}\right)$ $\delta 27.9$ (1C, Ad), 28.0 (1C, Ad), 30.0 (2C, Ad), 31.6 (2C, Ad), 37.9 (1C, Ad), 38.6 (2C, Ad), 43.9 (2C, $\left.\mathrm{CH}_{2}(\mathrm{NH}), \mathrm{Ad}\right), 100.4$ (1C, C5), 153.5 (2C, $\left.\mathrm{C} 2, \mathrm{C} 4\right), 163.4$ (1C, C6). HRMS (MALDI-TOF): $m / z[\mathrm{M}+\mathrm{H}]^{+}$calcd for $\mathrm{C}_{15} \mathrm{H}_{21} \mathrm{ClN}_{3}$ : 278.1419; observed: 278.1463.

$N$-(6-chloropyrimididin-4-yl)-N'-(1-Adamantyl)propan-1,3-diamine (5d). Obtained from dichloropyrimidine $(75 \mathrm{mg})$, amine $4 \mathrm{~d}(104 \mathrm{mg})$ in the presence of $\mathrm{K}_{2} \mathrm{CO}_{3}(276 \mathrm{mg})$ in $1 \mathrm{~mL}$ of DMF. Yield $96 \mathrm{mg}(60 \%)$, brownish viscous oil. ${ }^{1} \mathrm{H}-\mathrm{NMR}\left(\mathrm{CDCl}_{3}\right) \delta 1.52-1.66(\mathrm{~m}, 14 \mathrm{H}$, $\left.\mathrm{CH}_{2}, \mathrm{Ad}\right), 2.18(\mathrm{~s}, 3 \mathrm{H}, \mathrm{Ad}), 3.20-3.39\left(\mathrm{~m}, 5 \mathrm{H}, \mathrm{NH}, \mathrm{CH}_{2}(\mathrm{NH})\right), 6.51(\mathrm{~s}, 1 \mathrm{H}, \mathrm{H} 5), 8.34(\mathrm{~s}, 1 \mathrm{H}$, H2). ${ }^{13} \mathrm{C}-\mathrm{NMR}\left(\mathrm{CDCl}_{3}\right) \delta 29.3(3 \mathrm{C}, \mathrm{Ad}), 29.8\left(1 \mathrm{C}, \mathrm{CH}_{2}\right), 35.8$ (3C, $\left.\mathrm{Ad}\right), 36.7\left(1 \mathrm{C}, \mathrm{CH}_{2}(\mathrm{NH})\right.$ ), $38.7\left(1 \mathrm{C}, \mathrm{CH}_{2}(\mathrm{NH})\right), 42.2(3 \mathrm{C}, \mathrm{Ad}), 56.7\left(1 \mathrm{C}, \mathrm{C}_{\text {quat }}\right), 104.9$ (1C, C2), $156.8(1 \mathrm{C}, \mathrm{C} 4), 161.9$ (1C, C6), 162.2 (1C, C5). HRMS (MALDI-TOF): $m / z$ [M + H] ${ }^{+}$calcd for $\mathrm{C}_{17} \mathrm{H}_{26} \mathrm{ClN}_{4}: 321.1841$; observed: 321.1834 .

N-[4-(2-Adamantyl)piperazin-1-yl]-6-chloropyrimidine (5e). Obtained from dichloropyrimidine $(224 \mathrm{mg})$, amine $4 \mathbf{e}(113 \mathrm{mg})$ in the presence of $\mathrm{K}_{2} \mathrm{CO}_{3}(276 \mathrm{mg})$ in $1 \mathrm{~mL}$ of DMF. Yield $125 \mathrm{mg}(75 \%)$, brownish viscous oil. ${ }^{1} \mathrm{H}-\mathrm{NMR}\left(\mathrm{CDCl}_{3}\right) \delta 1.43\left(\mathrm{~d}, 2 \mathrm{H},{ }^{3} \mathrm{~J}=12.1 \mathrm{~Hz}, \mathrm{Ad}\right)$, 1.55-1.62 (m, 4H, Ad), 1.71-1.79 (m, 4H, Ad), 2.06 (s, 5H, Ad), 2.39-2.43 (m, 4H, $\left.\mathrm{CH}_{2}(\mathrm{~N})\right)$, 3.62 (br. s, $\left.4 \mathrm{H}, \mathrm{CH}_{2}(\mathrm{~N})\right), 6.47(\mathrm{~s}, 1 \mathrm{H}, \mathrm{H} 5), 8.35(\mathrm{~s}, 1 \mathrm{H}, \mathrm{H} 2) .{ }^{13} \mathrm{C}-\mathrm{NMR}\left(\mathrm{CDCl}_{3}\right) \delta 27.0(1 \mathrm{C}$, Ad), 27.3 (1C, Ad), 28.8 (2C, Ad), 31.1 (2C, Ad), 36.9 (2C, Ad), 37.5 (1C, Ad), 44.2 (2C, $\left.\mathrm{CH}_{2}(\mathrm{~N})\right), 48.8\left(2 \mathrm{C}, \mathrm{CH}_{2}(\mathrm{~N})\right), 67.0(1 \mathrm{C}, \mathrm{Ad}(\mathrm{N})), 101.0(1 \mathrm{C}, \mathrm{C} 2), 157.8(1 \mathrm{C}, \mathrm{C} 5), 159.7(1 \mathrm{C}$, C4), 162.0 (1C, C6). HRMS (MALDI-TOF): $m / z$ [M + H] ${ }^{+}$calcd for $\mathrm{C}_{18} \mathrm{H}_{26} \mathrm{ClN}_{4}$ : 333.1841; observed: 333.1866 .

N-[2-(1-Adamantyl)propan-2-yl]-6-chloropyrimidin-4-amine (5f). Obtained from dichloropyrimidine $(75 \mathrm{mg})$, amine $4 \mathrm{f}(98 \mathrm{mg})$ in the presence of $\mathrm{K}_{2} \mathrm{CO}_{3}(276 \mathrm{mg})$ in $1 \mathrm{~mL}$ of DMF. Yield $92 \mathrm{mg}(60 \%)$, yellowish viscous oil. ${ }^{1} \mathrm{H}-\mathrm{NMR}\left(\mathrm{CDCl}_{3}\right) \delta 1.15\left(\mathrm{~d}, 3 \mathrm{H},{ }^{3} \mathrm{~J}=6.3 \mathrm{~Hz}\right.$, $\left.\mathrm{CH}_{3}\right), 1.26-1.29\left(\mathrm{~m}, 2 \mathrm{H}, \mathrm{CH}_{2}(\mathrm{Ad})\right), 1.43-1.50(\mathrm{~m}, 6 \mathrm{H}, \mathrm{Ad}), 1.54-1.66(\mathrm{~m}, 6 \mathrm{H}, \mathrm{Ad}), 1.89$ (s, 3H, Ad), 3.68 (br. s, 1H, CHN), 5.51 (br. s, 1H, NH), 6.27 (s, 1H, H5), 8.28 (s, 1H, H2). ${ }^{13} \mathrm{C}-\mathrm{NMR}\left(\mathrm{CDCl}_{3}\right) \delta 23.0\left(1 \mathrm{C}, \mathrm{CH}_{3}\right), 28.4(3 \mathrm{C}, \mathrm{Ad}), 32.4\left(1 \mathrm{C}, \mathrm{C}_{\text {quat }}\right), 36.8(3 \mathrm{C}, \mathrm{Ad}), 42.8$ (4C, Ad, $\left.\mathrm{CH}_{2}(\mathrm{Ad})\right), 52.0\left(1 \mathrm{C}, \mathrm{CH}_{2}(\mathrm{NH})\right), 100.1$ (1C, C5), $158.4(2 \mathrm{C}, \mathrm{C} 2, \mathrm{C} 4), 161.9$ (1C, C6). HRMS (MALDI-TOF): $m / z[\mathrm{M}+\mathrm{H}]^{+}$calcd for $\mathrm{C}_{17} \mathrm{H}_{25} \mathrm{ClN}_{3}$ : 306.1732; observed: 306.1757 .

$\mathrm{N}$-[2-(1-Adamantyl)ethyl]-6-chloropyrimidin-4-amine (5g). Obtained from dichloropyrimidine $(75 \mathrm{mg})$, amine $4 \mathrm{~g}(90 \mathrm{mg})$ in the presence of $\mathrm{K}_{2} \mathrm{CO}_{3}(276 \mathrm{mg})$ in $1 \mathrm{~mL}$ of DMF. Yield $112 \mathrm{mg}(77 \%)$, yellowish glassy compound. ${ }^{1} \mathrm{H}-\mathrm{NMR}\left(\mathrm{CDCl}_{3}\right) \delta 1.35-1.38\left(\mathrm{~m}, 2 \mathrm{H}, \mathrm{CH}_{2}(\mathrm{Ad})\right)$, 1.48-1.55 (m, 6H, Ad), 1.57-1.73 (m, 6H, Ad), 1.95 (s, 3H, Ad), 3.22 (br. s, $\left.2 \mathrm{H}, \mathrm{CH}_{2} \mathrm{~N}\right), 5.62$ (br. s, NH), 6.29 (s, 1H, H5), 8.29 (s, 1H, H2). ${ }^{13} \mathrm{C}-\mathrm{NMR}\left(\mathrm{CDCl}_{3}\right) \delta 28.6$ (3C, Ad), 32.0 (1C, $\left.\mathrm{CH}_{2}(\mathrm{Ad})\right), 36.7\left(1 \mathrm{C}, \mathrm{C}_{\text {quat }}(\mathrm{Ad})\right), 37.0(3 \mathrm{C}, \mathrm{Ad}), 42.5$ (3C, $\left.\mathrm{Ad}\right), 43.5\left(1 \mathrm{C}, \mathrm{Ad}, \mathrm{CH}_{2}(\mathrm{NH})\right.$ ), 103.3 (1C, C5), 155.4 (1C, C4), 158.4 (1C, C2), 163.4 (1C, C6). HRMS (MALDI-TOF): $\mathrm{m} / z$ $[\mathrm{M}+\mathrm{H}]^{+}$calcd for $\mathrm{C}_{16} \mathrm{H}_{23} \mathrm{ClN}_{3}$ : 292.1575; observed: 292.1540.

Syntheses of N-(2-(1-Adamantyloxy)ethyl)-6-chloropyrazin-2-amine (6) and N-[2-(1Adamantyloxy)ethyl]-3-chloroisoquinolin-1-amine (7) were previously reported in ref. [31].

\subsection{Palladium-Catalyzed Amination of Chloroheterocycles-General Procedure}

A two-neck flask equipped with a condenser and a magnetic stirrer, flushed with dry argon, was charged with corresponding chloroheterocycle $(0.2 \mathrm{mmol}), \mathrm{Pd}(\mathrm{dba})_{2}$ (2.5-12 $\mathrm{mg}, 2-8 \mathrm{~mol} \%)$, phosphine ligand $(2.5-9 \mathrm{~mol} \%)$, and absolute dioxane $(2 \mathrm{~mL})$. The mixture was stirred for 2-3 $\mathrm{min}$, then corresponding amine $4(0.2-0.8 \mathrm{mmol})$ and $t \mathrm{BuONa}(0.375 \mathrm{mmol})$ were added, and the reaction mixture was refluxed for $24 \mathrm{~h}$. After cooling it down to ambient temperature, the reaction mixture was diluted with $\mathrm{CH}_{2} \mathrm{Cl}_{2}$, the solution filtered and evaporated in vacuo, and the residue was chromatographed on silica 
gel using a sequence of eluents: hexanes, hexanes- $\mathrm{CH}_{2} \mathrm{Cl}_{2}$ 2:1-1:1, $\mathrm{CH}_{2} \mathrm{Cl}_{2}, \mathrm{CH}_{2} \mathrm{Cl}_{2} / \mathrm{MeOH}$ 200:1-3:1.

$N, N^{\prime}$-bis[2-(1-adamantyloxy)ethyl]pyrimidine-4,6-diamine (8a). Obtained from chloroheterocycle $5 \mathbf{a}(61.5 \mathrm{mg})$, amine $4 \mathbf{a}(156 \mathrm{mg})$ in the presence of $\mathrm{Pd}(\mathrm{dba})_{2}(5 \mathrm{mg})$, DavePhos (3.5 mg) and $t \mathrm{BuONa}(29 \mathrm{mg})$. Eluent $\mathrm{CH}_{2} \mathrm{Cl}_{2} / \mathrm{MeOH}$ 50:1. Yield $57 \mathrm{mg}$ (61\%), yellowish viscous oil. ${ }^{1} \mathrm{H}-\mathrm{NMR}\left(\mathrm{CDCl}_{3}\right) \delta 1.55-1.64(\mathrm{~m}, 12 \mathrm{H}, \mathrm{Ad}), 1.72(\mathrm{~s}, 12 \mathrm{H}, \mathrm{Ad}), 2.14(\mathrm{~s}, 6 \mathrm{H}, \mathrm{Ad})$, 3.32-3.34 (m, 4H, $\left.\left.\mathrm{CH}_{2}(\mathrm{NH})\right)\right), 3.57\left(\mathrm{t}, 4 \mathrm{H},{ }^{3} \mathrm{~J}=5.1 \mathrm{~Hz}, \mathrm{CH}_{2}(\mathrm{O})\right), 5.14$ (br. s, 2H, NH), 5.29 (s, 1H, H5), 8.07 (s, 1H, H2). ${ }^{13} \mathrm{C}-\mathrm{NMR}\left(\mathrm{CDCl}_{3}\right) \delta 30.4$ (6C, Ad), 36.3 (6C, Ad), 41.5 (6C, Ad), $41.5\left(2 \mathrm{C}, \mathrm{CH}_{2}(\mathrm{NH})\right), 58.2\left(2 \mathrm{C}, \mathrm{CH}_{2}(\mathrm{O})\right), 72.5\left(2 \mathrm{C}, \mathrm{C}_{\text {quat }}(\mathrm{O})\right), 80.2$ (1C, C5), 157.5 (1C, C2), 162.7 (2C, C4, C6). HRMS (MALDI-TOF): $m / z[\mathrm{M}+\mathrm{H}]^{+}$calcd for $\mathrm{C}_{28} \mathrm{H}_{43} \mathrm{~N}_{4} \mathrm{O}_{2}$ : 467.3381; observed: 467.3344.

$N$-[2-(1-adamantyloxy)ethyl]-N'-[(1-adamantyl)methyl]pyrimidine-4,6-diamine (8b). Obtained from chloroheterocycle $5 \mathrm{a}(61.5 \mathrm{mg})$, amine $4 \mathrm{~b}(132 \mathrm{mg})$ in the presence of $\mathrm{Pd}(\mathrm{dba})_{2}$ (5 mg), DavePhos (3.5 mg) and $t$ BuONa $(29 \mathrm{mg})$. Eluent $\mathrm{CH}_{2} \mathrm{Cl}_{2} / \mathrm{MeOH}$ 50:1. Yield $35 \mathrm{mg}(40 \%)$, yellowish viscous oil. ${ }^{1} \mathrm{H}-\mathrm{NMR}\left(\mathrm{CDCl}_{3}\right) \delta 1.52-1.71(\mathrm{~m}, 24 \mathrm{H}, \mathrm{Ad}), 1.97$ (s, 3H, Ad), $2.12(\mathrm{~s}, 3 \mathrm{H}, \mathrm{Ad}), 2.83\left(\mathrm{~d}, 2 \mathrm{H},{ }^{3} \mathrm{~J}=5.9 \mathrm{~Hz}, \mathrm{CH}_{2}(\mathrm{NH})\right), 3.35(\mathrm{q}, 2 \mathrm{H}, 3 \mathrm{~J}=5.1 \mathrm{~Hz}$, $\mathrm{CH}_{2}(\mathrm{NH})$ ), $3.57\left(\mathrm{t}, 2 \mathrm{H},{ }^{3} \mathrm{~J}=5.9 \mathrm{~Hz}, \mathrm{CH}_{2}(\mathrm{O})\right), 5.20$ (br. s, NH), 5.27 (s, 1H, H5), 8.00 (s, 1H, H2). ${ }^{13} \mathrm{C}-\mathrm{NMR}\left(\mathrm{CDCl}_{3}\right) \delta 28.2$ (3C, Ad), 30.4 (3C, Ad), 36.3 (3C, Ad), 36.8 (3C, Ad), 40.4 (3C, Ad), $41.5(3 \mathrm{C}, \mathrm{Ad}), 42.0\left(1 \mathrm{C}, \mathrm{CH}_{2}(\mathrm{NH})\right), 53.6\left(1 \mathrm{C}, \mathrm{CH}_{2}(\mathrm{NH})\right), 58.2\left(1 \mathrm{C}, \mathrm{CH}_{2}(\mathrm{O})\right)$, 72.5 (1C, $\left.\mathrm{C}_{\text {quat }}(\mathrm{O})\right), 79.3$ (1C, C5), 156.6 (1C, C2), 162.6 (2C, C4, C6). HRMS (MALDI-TOF): $m / z[\mathrm{M}+\mathrm{H}]^{+}$calcd for $\mathrm{C}_{27} \mathrm{H}_{40} \mathrm{~N}_{4} \mathrm{O}: 437.3275$; observed: 437.3255 .

N-[2-(1-adamantyloxy)ethyl]-N'-[2-(1-adamantyl)propan]pyrimidine-4,6-diamine (8f). Obtained from chloroheterocycle $5 \mathbf{a}(61.5 \mathrm{mg})$, amine $\mathbf{4 f}(155 \mathrm{mg})$ in the presence of $\mathrm{Pd}(\mathrm{dba})_{2}$ (5 mg), DavePhos (3.5 mg) and $t$ BuONa (29 mg). Eluent $\mathrm{CH}_{2} \mathrm{Cl}_{2} / \mathrm{MeOH}$ 50:1. Yield $43 \mathrm{mg}$ $(46 \%)$, yellowish viscous oil. ${ }^{1} \mathrm{H}-\mathrm{NMR}\left(\mathrm{CDCl}_{3}\right) \delta 1.14\left(\mathrm{~d}, 3 \mathrm{H},{ }^{3} \mathrm{~J}=6.3 \mathrm{~Hz}, \mathrm{CH}_{3}\right), 1.49-1.51$ (m, 6H, Ad, $\left.\mathrm{CH}_{2}\right), 1.55-1.67$ (m, 14H, Ad, $\left.\mathrm{CH}_{2}\right), 1.70-1.73$ (m, 6H, Ad), 1.90 (s, 3H, Ad), 2.12 (s, 3H, Ad), 3.32-3.36 (q, 2H, $\left.{ }^{3} J=5.3 \mathrm{~Hz}, \mathrm{CH}_{2}(\mathrm{NH})\right), 3.56-3.60\left(\mathrm{~m}, 3 \mathrm{H}, \mathrm{CH}(\mathrm{NH}), \mathrm{CH}_{2}(\mathrm{O})\right)$, $5.23(\mathrm{~s}, 1 \mathrm{H}, \mathrm{H} 5), 8.04(\mathrm{~s}, 1 \mathrm{H}, \mathrm{H} 2)$, $\mathrm{NH}$ protons were not unambiguously attributed.${ }^{13} \mathrm{C}$ $\mathrm{NMR}\left(\mathrm{CDCl}_{3}\right) \delta 23.2\left(1 \mathrm{C}, \mathrm{CH}_{3}\right), 28.2$ (3C, Ad), 30.4 (3C, Ad), 32.4 (1C, $\left.\mathrm{C}_{\text {quat }}(\mathrm{Ad})\right), 36.3$ (3C, Ad), 36.9 (3C, Ad), 41.5 (3C, Ad), 42.0 (1C, $\left.\mathrm{CH}_{2}(\mathrm{Ad})\right), 42.6$ (1C, $\left.\mathrm{CH}_{2}(\mathrm{NH})\right), 42.9$ (3C, Ad), $52.3\left(1 \mathrm{C}, \mathrm{CH}_{2}(\mathrm{NH})\right), 58.2\left(1 \mathrm{C}, \mathrm{CH}_{2}(\mathrm{O})\right), 72.4\left(1 \mathrm{C}, \mathrm{C}_{\text {quat }}(\mathrm{O})\right), 79.6(1 \mathrm{C}, \mathrm{C} 5), 157.7(1 \mathrm{C}, \mathrm{C} 2)$, 161.3 (1C, C4), 162.8 (1C, C6). HRMS (MALDI-TOF): $m / z[\mathrm{M}+\mathrm{H}]^{+}$calcd for $\mathrm{C}_{29} \mathrm{H}_{44} \mathrm{~N}_{4} \mathrm{O}$ : 465.3588; observed: 465.3603 .

$N, N^{\prime}$-bis[2-(1-adamantyloxy)ethyl]pyrazine-2,6-diamine(9a). Obtained from chloroheterocycle $6(61.5 \mathrm{mg})$, amine $4 \mathrm{a}(156 \mathrm{mg})$ in the presence of $\mathrm{Pd}(\mathrm{dba})_{2}(5 \mathrm{mg}), \mathrm{Ph}$-JosiPhos $(5 \mathrm{mg})$ and $t \mathrm{BuONa}(29 \mathrm{mg})$. Eluent $\mathrm{CH}_{2} \mathrm{Cl}_{2} / \mathrm{MeOH} 50: 1$. Yield $84 \mathrm{mg}(90 \%)$, yellowish viscous oil. ${ }^{1} \mathrm{H}-\mathrm{NMR}\left(\mathrm{CDCl}_{3}\right) \delta 1.56-1.65(\mathrm{~m}, 12 \mathrm{H}, \mathrm{Ad}), 1.72$ (s, 12H, Ad), 2.13 (s, 6H, Ad), 3.39-3.43 (m, 4H, $\left.\mathrm{CH}_{2}(\mathrm{NH})\right), 3.56-3.59\left(\mathrm{~m}, 4 \mathrm{H}, \mathrm{CH}_{2}(\mathrm{O})\right), 4.68(\mathrm{~s}, 2 \mathrm{H}, \mathrm{NH}), 7.17$ (s, 2H, H3, H5). ${ }^{13} \mathrm{C}-\mathrm{NMR}\left(\mathrm{CDCl}_{3}\right) \delta 30.5$ (6C, Ad), 36.4 (6C, Ad), 41.6 (6C, Ad), 41.9 (2C, $\left.\mathrm{CH}_{2}(\mathrm{NH})\right), 58.5\left(2 \mathrm{C}, \mathrm{CH}_{2}(\mathrm{O})\right), 72.4\left(2 \mathrm{C}, \mathrm{C}_{\text {quat }}(\mathrm{O})\right), 118.4(2 \mathrm{C}, \mathrm{C} 3, \mathrm{C} 5), 153.4(2 \mathrm{C}, \mathrm{C} 2, \mathrm{C} 6)$. HRMS (MALDI-TOF): $m / z$ [M + H] $]^{+}$calcd for $\mathrm{C}_{28} \mathrm{H}_{43} \mathrm{~N}_{4} \mathrm{O}_{2}$ : 467.3381; observed: 467.3419.

N-[2-(1-adamantyloxy)ethyl]-N'-[(1-adamantyl)methyl]pyrazine-2,6-diamine (9b). Obtained from chloroheterocycle $6(61.5 \mathrm{mg})$, amine $4 \mathbf{b}(132 \mathrm{mg})$ in the presence of $\mathrm{Pd}(\mathrm{dba})_{2}(5 \mathrm{mg})$, Ph-JosiPhos (5 mg) and $t$ BuONa $(29 \mathrm{mg})$. Eluent $\mathrm{CH}_{2} \mathrm{Cl}_{2} / \mathrm{MeOH}$ 100:1. Yield $37 \mathrm{mg}(42 \%)$, yellowish viscous oil. ${ }^{1} \mathrm{H}-\mathrm{NMR}\left(\mathrm{CDCl}_{3}\right) \delta 1.52-1.72(\mathrm{~m}, 24 \mathrm{H}, \mathrm{Ad}), 1.96(\mathrm{~s}, 3 \mathrm{H}, \mathrm{Ad}), 2.12$ (s, 3H, Ad), $2.95\left(\mathrm{~d}, 2 \mathrm{H},{ }^{3} \mathrm{~J}=6.7 \mathrm{~Hz}, \mathrm{CH}_{2}(\mathrm{NH})\right), 3.39\left(\mathrm{q}, 2 \mathrm{H},{ }^{3} \mathrm{~J}=5.5 \mathrm{~Hz}, \mathrm{CH}_{2}(\mathrm{NH})\right), 3.57$ $\left(\mathrm{t}, 2 \mathrm{H},{ }^{3} \mathrm{~J}=5.5 \mathrm{~Hz}, \mathrm{CH}_{2}(\mathrm{O})\right), 4.36\left(\mathrm{t}, 1 \mathrm{H},{ }^{3} \mathrm{~J}=5.9 \mathrm{~Hz}, \mathrm{NH}\right), 4.66\left(\mathrm{t}, 1 \mathrm{H},{ }^{3} \mathrm{~J}=5.5 \mathrm{~Hz}, \mathrm{NH}\right)$, 7.12 (s, 1H, H5), 7.15 (s, 1H, H3). ${ }^{13} \mathrm{C}-\mathrm{NMR}\left(\mathrm{CDCl}_{3}\right) \delta 28.2$ (3C, Ad), 30.4 (3C, Ad), 34.1 (1C, $\left.\mathrm{C}_{\text {quat }}\right), 36.3$ (3C, Ad), 36.9 (3C, Ad), 40.4 (3C, Ad), 41.5 (3C, Ad), $41.9\left(1 \mathrm{C}, \mathrm{CH}_{2}(\mathrm{NH})\right)$, $53.2\left(1 \mathrm{C}, \mathrm{CH}_{2}(\mathrm{Ad})\right), 58.4\left(1 \mathrm{C}, \mathrm{CH}_{2}(\mathrm{O})\right), 72.4\left(1 \mathrm{C}, \mathrm{C}_{\text {quat }}(\mathrm{O})\right), 115.4(1 \mathrm{C}, \mathrm{C} 3), 115.7(1 \mathrm{C}, \mathrm{C} 5)$, $153.6(1 \mathrm{C}, \mathrm{C} 2), 154.3(1 \mathrm{C}, \mathrm{C} 6)$. HRMS (MALDI-TOF): $m / z[\mathrm{M}+\mathrm{H}]^{+}$calcd for $\mathrm{C}_{27} \mathrm{H}_{41} \mathrm{~N}_{4} \mathrm{O}$ : 437.3275; observed: 437.3261 .

N-[2-(1-adamantyloxy)ethyl]-N'-[2-(1-adamantyl)ethan]pyrazine-2,6-diamine (9g). Obtained from chloroheterocycle $6(61.5 \mathrm{mg})$, amine $4 \mathrm{~g}(143 \mathrm{mg})$ in the presence of $\mathrm{Pd}(\mathrm{dba})_{2}(5 \mathrm{mg})$, 
Ph-JosiPhos (5 mg) and $t$ BuONa (29 mg). Eluent $\mathrm{CH}_{2} \mathrm{Cl}_{2} / \mathrm{MeOH}$ 50:1. Yield $43 \mathrm{mg}(48 \%)$, yellowish viscous oil. ${ }^{1} \mathrm{H}-\mathrm{NMR}\left(\mathrm{CDCl}_{3}\right) \delta 1.50-1.84\left(\mathrm{~m}, 26 \mathrm{H}, \mathrm{Ad}, \mathrm{CH}_{2}(\mathrm{Ad})\right), 2.13(\mathrm{~s}, 6 \mathrm{H}$, Ad), 3.20-3.25 (m, 2H, $\left.\mathrm{CH}_{2}(\mathrm{NH})\right), 3.39\left(\mathrm{q}, 2 \mathrm{H},{ }^{3} \mathrm{~J}=5.4 \mathrm{~Hz}, \mathrm{CH}_{2}(\mathrm{NH})\right), 3.56\left(\mathrm{t}, 2 \mathrm{H},{ }^{3} \mathrm{~J}=5.3 \mathrm{~Hz}\right.$, $\left.\mathrm{CH}_{2}(\mathrm{O})\right), 4.30\left(\mathrm{t}, 1 \mathrm{H},{ }^{3} \mathrm{~J}=5.4, \mathrm{NH}\right), 4.68\left(\mathrm{t}, 1 \mathrm{H},{ }^{3} \mathrm{~J}=5.6 \mathrm{~Hz}, \mathrm{NH}\right), 7.14(\mathrm{~s}, 1 \mathrm{H}, \mathrm{H} 3), 7.17(\mathrm{~s}, 1 \mathrm{H}$, H5). ${ }^{13} \mathrm{C}-\mathrm{NMR}\left(\mathrm{CDCl}_{3}\right) \delta 27.9\left(1 \mathrm{C}, \mathrm{CH}_{2}(\mathrm{Ad})\right), 30.4$ (3C, Ad), 31.5 (3C, Ad), 31.6 (3C, Ad), $31.8\left(1 \mathrm{C}, \mathrm{C}_{\text {quat }}\right), 36.4(3 \mathrm{C}, \mathrm{Ad}), 38.2\left(1 \mathrm{C}, \mathrm{CH}_{2}(\mathrm{NH})\right), 39.0$ (3C, $\left.\mathrm{Ad}\right), 41.5$ (3C, Ad), 41.8 (1C, $\left.\mathrm{CH}_{2}(\mathrm{NH})\right), 58.5\left(1 \mathrm{C}, \mathrm{CH}_{2}(\mathrm{O})\right), 72.3\left(1 \mathrm{C}, \mathrm{C}_{\text {quat }}(\mathrm{O})\right), 117.6(1 \mathrm{C}, \mathrm{C} 3), 118.6(1 \mathrm{C}, \mathrm{C} 5), 153.4(2 \mathrm{C}$, C2, C6). HRMS (MALDI-TOF): $m / z[\mathrm{M}+\mathrm{H}]^{+}$calcd for $\mathrm{C}_{28} \mathrm{H}_{43} \mathrm{~N}_{4} \mathrm{O}: 451.3431$; observed: 451.3454.

N-[2-(1-adamantyloxy)ethyl]-N'-[2-(2-adamantyl)ethan]pyrazine-2,6-diamine (9h). Obtained from chloroheterocycle $6(61.5 \mathrm{mg})$, amine $4 \mathrm{~h}(143 \mathrm{mg})$ in the presence of $\mathrm{Pd}(\mathrm{dba})_{2}$ (5 mg), Ph-JosiPhos (5 mg) and $t$ BuONa (29 mg). Eluent $\mathrm{CH}_{2} \mathrm{Cl}_{2} / \mathrm{MeOH}$ 50:1. Yield 32 $\mathrm{mg}(36 \%)$, yellowish viscous oil. ${ }^{1} \mathrm{H}-\mathrm{NMR}\left(\mathrm{CDCl}_{3}\right) \delta 1.51-1.94\left(\mathrm{~m}, 29 \mathrm{H}, \mathrm{Ad}, \mathrm{CH}_{2}(\mathrm{Ad})\right)$, $2.14(\mathrm{~s}, 3 \mathrm{H}, \mathrm{Ad}), 3.22-3.26\left(\mathrm{~m}, 2 \mathrm{H}, \mathrm{CH}_{2}(\mathrm{NH})\right), 3.37-3.42\left(\mathrm{~m}, 2 \mathrm{H}, \mathrm{CH}_{2}(\mathrm{NH})\right), 3.57(\mathrm{t}, 2 \mathrm{H}$, $\left.{ }^{3} J=5.4 \mathrm{~Hz}, \mathrm{CH}_{2}(\mathrm{O})\right), 4.17(\mathrm{~s}, 1 \mathrm{H}, \mathrm{NH}), 4.69$ (s, 1H, NH), 7.13 (s, 1H, H3), 7.18 (s, 1H, H5). ${ }^{13} \mathrm{C}-\mathrm{NMR}\left(\mathrm{CDCl}_{3}\right) \delta 28.5$ (1C, Ad), 28.6 (1C, Ad), 30.4 (3C, Ad), 36.3 (1C, Ad), 36.4 (3C, Ad), 36.9 (2C, Ad), 37.0 (2C, Ad), 41.5 (3C, Ad), 41.9 (1C, $\left.\mathrm{CH}_{2}(\mathrm{Ad})\right), 42.0\left(1 \mathrm{C}, \mathrm{CH}_{2}(\mathrm{NH})\right), 42.4$ (1C, Ad), $42.5(2 \mathrm{C}, \mathrm{Ad}), 44.0\left(1 \mathrm{C}, \mathrm{CH}_{2}(\mathrm{NH})\right), 58.5\left(1 \mathrm{C}, \mathrm{CH}_{2}(\mathrm{O})\right), 72.3\left(1 \mathrm{C}, \mathrm{C}_{\text {quat }}(\mathrm{O})\right), 117.6$ (1C, C3), 118.7 (1C, C5), 153.4 (1C, C6), 153.5 (1C, C2). HRMS (MALDI-TOF): $m / z[\mathrm{M}+\mathrm{H}]^{+}$ calcd for $\mathrm{C}_{28} \mathrm{H}_{43} \mathrm{~N}_{4} \mathrm{O}$ : 451.3431; observed: 451.3430 .

$N, N^{\prime}$-bis[2-(1-adamantyloxy)ethyl]isoquinoline-1,3-diamine (10a). Obtained from chloroheterocycle $7(71.5 \mathrm{mg})$, amine $4 \mathrm{a}(156 \mathrm{mg})$ in the presence of $\mathrm{Pd}(\mathrm{dba})_{2}(5 \mathrm{mg})$, DavePhos (3.5 mg) and $t \mathrm{BuONa}(29 \mathrm{mg})$. Eluent $\mathrm{CH}_{2} \mathrm{Cl}_{2} / \mathrm{MeOH}$ 50:1. Yield $79 \mathrm{mg}(77 \%)$, yellowish viscous oil. ${ }^{1} \mathrm{H}-\mathrm{NMR}\left(\mathrm{CDCl}_{3}\right) \delta 1.57-1.65(\mathrm{~m}, 12 \mathrm{H}, \mathrm{Ad}), 1.76(\mathrm{~s}, 12 \mathrm{H}, \mathrm{Ad}), 2.15(\mathrm{~s}, 6 \mathrm{H}$, Ad), $3.37\left(\mathrm{t}, 2 \mathrm{H},{ }^{3} \mathrm{~J}=5.6 \mathrm{~Hz}, \mathrm{CH}_{2}(\mathrm{NH})\right), 3.63-3.67\left(\mathrm{~m}, 4 \mathrm{H}, \mathrm{CH}_{2}(\mathrm{NH}), \mathrm{CH}_{2}(\mathrm{O})\right), 3.70-3.72$ (m, 2H, $\left.\mathrm{CH}_{2}(\mathrm{O})\right), 4.62$ (br. s., 1H, NH), 5.65 (s, 1H, NH), 5.87 (s, 1H, H4), 7.04 (ddd, 1H, $\left.{ }^{3} J=8.2,{ }^{3} J=6.4,{ }^{4} J=1.7 \mathrm{~Hz}, \mathrm{H} 7\right), 7.33-7.39$ (m, 2H, H5, H6), $7.54\left(\mathrm{~d}, 1 \mathrm{H},{ }^{3} J=8.3 \mathrm{~Hz}, \mathrm{H} 8\right)$. ${ }^{13} \mathrm{C}-\mathrm{NMR}\left(\mathrm{CDCl}_{3}\right) \delta 30.4(6 \mathrm{C}, \mathrm{Ad}), 36.3$ (6C, Ad), 41.5 (3C, Ad), 41.6 (3C, Ad), 41.7 (1C, $\left.\mathrm{CH}_{2}(\mathrm{NH})\right), 43.3\left(1 \mathrm{C}, \mathrm{CH}_{2}(\mathrm{NH})\right), 58.6\left(1 \mathrm{C}, \mathrm{CH}_{2}(\mathrm{O})\right), 58.9\left(1 \mathrm{C}, \mathrm{CH}_{2}(\mathrm{O})\right), 72.2\left(2 \mathrm{C}, \mathrm{C}_{\text {quat }}(\mathrm{O})\right)$, 85.7 (1C, C4), 113.1 (1C, C8a), 120.6 (1C, C5), 121.6 (1C, C8), 125.1 (1C, C7), 129.5 (1C, C6), 140.5 (1C, C4a), 154.3 (1C, C1), 154.8 (1C, C3). HRMS (MALDI-TOF): $m / z[M+H]^{+}$calcd for $\mathrm{C}_{33} \mathrm{H}_{46} \mathrm{~N}_{3} \mathrm{O}_{2}$ : 516.3584; observed: 516.3587 .

$N^{3}$-(1-adamantylmethyl)-N1-[2-(1-adamantyloxy)ethyl]isoquinoline-1,3-diamine (10b). Obtained from chloroheterocycle $7(71.5 \mathrm{mg})$, amine $4 \mathrm{~b}(132 \mathrm{mg})$ in the presence of $\mathrm{Pd}(\mathrm{dba})_{2}$ (5 mg), DavePhos (3.5 mg) and $t$ BuONa $(29 \mathrm{mg})$. Eluent $\mathrm{CH}_{2} \mathrm{Cl}_{2} / \mathrm{MeOH}$ 200:1. Yield $61 \mathrm{mg}(62 \%)$, green viscous oil. ${ }^{1} \mathrm{H}-\mathrm{NMR}\left(\mathrm{CDCl}_{3}\right) \delta 1.62-1.77(\mathrm{~m}, 24 \mathrm{H}, \mathrm{Ad}), 2.00(\mathrm{~s}, 3 \mathrm{H}, \mathrm{Ad})$, 2.16 (s, 3H, Ad), 2.91 (s, 2H, $\left.\mathrm{CH}_{2}(\mathrm{NH})\right), 3.67-3.76\left(\mathrm{~m}, 4 \mathrm{H}, \mathrm{CH}_{2}(\mathrm{NH}), \mathrm{CH}_{2}(\mathrm{O})\right), 4.27$ (br. s, 1H, NH), 5.82 (s, 1H, H4), 7.00-7.04 (m, 1H, H7), 7.32-7.37 (m, 2H, H5, H6), 7.51 (d, 1H, $\left.{ }^{3} \mathrm{~J}=8.4 \mathrm{~Hz}, \mathrm{H} 8\right), 1 \mathrm{NH}$ proton was not unambiguously attributed. ${ }^{13} \mathrm{C}-\mathrm{NMR}\left(\mathrm{CDCl}_{3}\right) \delta 28.4$ (3C, Ad), 30.5 (3C, Ad), 33.9 (1C, $\left.C_{\text {quat }}(\mathrm{Ad})\right), 36.4$ (3C, Ad), 37.1 (3C, Ad), 40.7 (3C, Ad), $41.7\left(4 \mathrm{C}, \mathrm{Ad}, \mathrm{CH}_{2}(\mathrm{Ad})\right), 55.2\left(1 \mathrm{C}, \mathrm{CH}_{2}(\mathrm{NH})\right), 58.9\left(1 \mathrm{C}, \mathrm{CH}_{2}(\mathrm{O})\right), 72.4\left(1 \mathrm{C}, \mathrm{C}_{\text {quat }}(\mathrm{O})\right), 84.9$ (1C, C4), 113.0 (1C, C8a), 120.4 (1C, C5), 121.6 (1C, C8), 125.1 (1C, C7), 129.5 (1C, C6), 140.7 (1C, C4a), 154.7 (1C, C1), 155.1 (1C, C3). HRMS (MALDI-TOF): $m / z[M+\mathrm{H}]^{+}$calcd for $\mathrm{C}_{32} \mathrm{H}_{44} \mathrm{~N}_{3} \mathrm{O}: 486.3479$; observed: 486.3506 .

$N^{3}$-[2-(1-adamantyl)-1-methylethyl]-N $N^{1}$-[2-(1-adamantyloxy)ethyl]isoquinoline-1,3-diamine (10f). Obtained from chloroheterocycle $7(71.5 \mathrm{mg})$, amine $\mathbf{4 f}(155 \mathrm{mg})$ in the presence of $\mathrm{Pd}(\mathrm{dba})_{2}(5 \mathrm{mg})$, DavePhos (3.5 mg) and $t \mathrm{BuONa}(29 \mathrm{mg})$. Eluent $\mathrm{CH}_{2} \mathrm{Cl}_{2} / \mathrm{MeOH} 200: 1$. Yield $69 \mathrm{mg}(67 \%)$, green viscous oil. ${ }^{1} \mathrm{H}-\mathrm{NMR}\left(\mathrm{CDCl}_{3}\right) \delta 1.23\left(\mathrm{~d}, 3 \mathrm{H},{ }^{3} \mathrm{~J}=6.2 \mathrm{~Hz}, \mathrm{CH}_{3}\right)$, 1.58-1.69 (m, 20H, Ad, $\left.\mathrm{CH}_{2}\right), 1.76-1.77$ (m, 6H, Ad), 1.93 (s, 3H, Ad), 2.15 (s, 3H, Ad), 3.68-3.78 (m, 5H, $\left.\mathrm{CH}_{2}(\mathrm{NH}), \mathrm{CH}(\mathrm{NH}), \mathrm{CH}_{2}(\mathrm{O})\right), 4.17$ (br. s, 1H, NH), 5.81 (s, 1H, H4), 7.00-7.05 (m, 1H, H7), 7.33-7.38 (m, 2H, H5, H6), 7.52 (d, 1H, $\left.{ }^{3} \mathrm{~J}=8.3 \mathrm{~Hz}, \mathrm{H} 8\right), 1 \mathrm{NH}$ proton was not unambiguously attributed. ${ }^{13} \mathrm{C}-\mathrm{NMR}\left(\mathrm{CDCl}_{3}\right) \delta 23.4\left(1 \mathrm{C}, \mathrm{CH}_{3}\right), 28.7(3 \mathrm{C}, \mathrm{Ad}), 30.5$ (3C, Ad), 32.6 (1C, $\left.C_{\text {quat }}(\mathrm{Ad})\right), 36.4$ (3C, Ad), 37.0 (3C, Ad), 41.7 (4C, Ad, CH), 42.9 (3C, $\mathrm{Ad}), 43.3\left(1 \mathrm{C}, \mathrm{CH}_{2}(\mathrm{NH})\right), 52.7\left(1 \mathrm{C}, \mathrm{CH}_{2}(\mathrm{NH})\right), 58.7\left(1 \mathrm{C}, \mathrm{CH}_{2}(\mathrm{O})\right), 72.4\left(1 \mathrm{C}, \mathrm{C}_{\text {quat }}(\mathrm{O})\right), 85.1$ 
(1C, C4), 112.9 (1C, C8a), 120.2 (1C, C5), 121.7 (1C, C8), 125.0 (1C, C7), 129.5 (1C, C6), 140.7 (1C, C4a), $153.2(1 \mathrm{C}, \mathrm{C} 1), 154.4(1 \mathrm{C}, \mathrm{C} 3)$. HRMS (MALDI-TOF): $m / z[\mathrm{M}+\mathrm{H}]^{+}$calcd for $\mathrm{C}_{34} \mathrm{H}_{48} \mathrm{~N}_{3} \mathrm{O}$ : 514.3792; observed: 514.3806 .

$N^{3}$-[2-(1-adamantyl)ethyl]-N $N^{1}$-[2-(1-adamantyloxy)ethyl]isoquinoline-1,3-diamine $(\mathbf{1 0 g}) . \mathrm{Ob}$ tained from chloroheterocycle $7(71.5 \mathrm{mg})$, amine $4 \mathrm{~g}(143 \mathrm{mg})$ in the presence of $\mathrm{Pd}(\mathrm{dba})_{2}$ (5 mg), DavePhos (3.5 mg) and $t$ BuONa $(29 \mathrm{mg})$. Eluent $\mathrm{CH}_{2} \mathrm{Cl}_{2} / \mathrm{MeOH}$ 150:1. Yield $43 \mathrm{mg}(43 \%)$, green viscous oil. ${ }^{1} \mathrm{H}-\mathrm{NMR}\left(\mathrm{CDCl}_{3}\right) \delta 1.57-1.77\left(\mathrm{~m}, 26 \mathrm{H}, \mathrm{Ad}, \mathrm{CH}_{2}\right), 1.98$ (s, 3H, Ad), 2.15 (s, 3H, Ad), 3.17-3.21 (m, 2H, $\left.\mathrm{CH}_{2}(\mathrm{NH})\right)$, 3.65-3.71 (m, 4H, $\mathrm{CH}_{2}(\mathrm{NH})$, $\left.\mathrm{CH}_{2}(\mathrm{O})\right), 5.69$ (br. s, 1H, NH), 5.81 (s, 1H, H4), $7.04\left(\mathrm{~m}, 1 \mathrm{H},{ }^{3} \mathrm{~J}=8.1 \mathrm{~Hz}, \mathrm{H7}\right), 7.34-7.40$ (m, 2H, H5, H6), 7.51-7.54 (m, 1H, H8), $1 \mathrm{NH}$ proton was not unambiguously attributed HRMS (MALDI-TOF): $m / z[\mathrm{M}+\mathrm{H}]^{+}$calcd for $\mathrm{C}_{33} \mathrm{H}_{46} \mathrm{~N}_{3} \mathrm{O}: 500.3635$; observed: 500.3653 .

\section{Conclusions}

To sum up, we have investigated a synthetic approach to adamantane-containing 4,6-diaminopyrimidine, 2,6-diaminopyrazine, and 1,3-diaminoisoquinoline based on consequent substitution of chlorine atoms in the corresponding dichloroheterocycle by means of convenient nucleophilic substitution and Pd-catalyzed amination, respectively. Selective monoamination of 4,6-diaminopyrimidine proceeds under catalyst-free conditions with products yields from good to excellent. Synthesis of 4,6-diaminopyrimidine, 2,6-diaminopyrazine and 1,3-diaminoisoquinoline by Pd-catalyzed amination of aminochloroderivatives is complicated by $N, N$-diarylation, leading to formation of oligomers; therefore, to suppress the side products formation, 4-fold excess of amine is required. Adamantane-containing 4,6-dialkylaminopyrimidines and 1,3-dialkylaminoisoquinolines have been obtained in moderate to good yields (40-60\%) using DavePhos as a ligand while the use of Ph-JosiPhos ligand is necessary for the synthesis of adamantylated 2,6-diaminopyrazines. It has been shown that adamantane-containing 6-chloro-4-aminopyrimidines exhibit prototropic tautomerism, which was observed and quantitatively characterized by NMR-spectroscopy. Tautomerism between amine and imine forms of the $N$-heteroarylated derivatives of adamantaneamines is held responsible to the formation of $N, N$-diarylated species.

Supplementary Materials: The following are available online. Experimental details of studies of prototropic equilibria.

Author Contributions: Conceptualization, I.P.B. and A.D.A., Methodology, A.S.A. and A.D.K., Investigation, A.D.K., A.S.A., and O.A.M., Resources, E.N.S., B.S.O., and I.A.N., Data curation, V.A.R., Writing-Original draft preparation, A.S.A., Writing-Review and editing, I.P.B. and A.D.A., Visualization, A.S.A., Supervision, I.P.B., Project administration, A.D.A., Funding acquisition, A.D.A. and I.P.B. All authors have read and agreed to the published version of the manuscript.

Funding: This research was funded by the RFBR, grant number 17-03-00888.

Data Availability Statement: The data presented in this study are available in Supplementary Materials or on request from the corresponding author.

Acknowledgments: The study of prototropic equlibria was fulfilled using an Agilent 400-MR NMR spectrometer purchased by the MSU Development Program.

Conflicts of Interest: The authors declare no conflict of interest. The funders had no role in the design of the study, in the collection, analyses, or interpretation of data, in the writing of the manuscript or in the decision to publish the results.

Sample Availability: Samples of the compounds are not available from the authors. 


\section{References}

1. Reddick, J.J.; Saha, S.; Lee, J.-M.; Melnick, J.S.; Perkins, J.; Begley, T.P. The mechanism of action of bacimethrin, a naturally occurring thiamin antimetabolite. Bioorg. Med. Chem. Lett. 2001, 11, 2245-2248. [CrossRef]

2. Liang, X.; Wang, B.; Chen, C.; Wang, A.; Hu, C.; Zou, F.; Yu, K.; Liu, Q.; Li, F.; Hu, Z.; et al. Discovery of N-(4-(6Acetamidopyrimidin-4-yloxy)phenyl)-2-(2-(trifluoromethyl)phenyl)acetamide (CHMFL-FLT3-335) as a Potent FMS-like Tyrosine Kinase 3 Internal Tandem Duplication (FLT3-ITD) Mutant Selective Inhibitor for Acute Myeloid Leukemia. J. Med. Chem. 2019, 62, 875-892. [CrossRef]

3. Manz, T.D.; Sivakumaren, S.C.; Yasgar, A.; Hall, M.D.; Davis, M.I.; Seo, H.-S.; Card, J.D.; Ficarro, S.B.; Shim, H.; Marto, J.A.; et al. Structure-Activity Relationship Study of Covalent Pan-phosphatidylinositol 5-Phosphate 4-Kinase Inhibitors. ACS Med. Chem. Lett. 2020, 11, 346-352. [CrossRef] [PubMed]

4. Gong, B.; Hong, F.; Kohm, C.; Jenkins, S.; Tulinsky, J.; Bhatt, R.; de Vries, P.; Singer, J.W.; Klein, P. Synthesis, SAR, and antitumor properties of diamino-C,N-diarylpyrimidine positional isomers: Inhibitors of lysophosphatidic acid acyltransferase- $\beta$. Bioorg. Med. Chem. Lett. 2004, 14, 2303-2308. [CrossRef] [PubMed]

5. Reich, S.H.; Sprengeler, P.A.; Chiang, G.G.; Appleman, J.R.; Chen, J.; Clarine, J.; Eam, B.; Ernst, J.T.; Han, Q.; Goel, V.K.; et al. Structure-based Design of Pyridone-Aminal eFT508 Targeting Dysregulated Translation by Selective Mitogen-activated Protein Kinase Interacting Kinases 1 and 2 (MNK1/2) Inhibition. J. Med. Chem. 2018, 61, 3516-3540. [CrossRef] [PubMed]

6. Mologni, L.; Dalla Via, M.; Chilin, A.; Palumbo, M.; Marzaro, G. Discovery of wtRET and V804MRET Inhibitors: From Hit to Lead. ChemMedChem 2017, 12, 1390-1398. [CrossRef]

7. Zhang, Y.; Lv, H.; Luo, L.; Xu, Y.; Pan, Y.; Wang, Y.; Lin, H.; Xiong, J.; Guo, P.; Zhang, J.; et al. Design, synthesis and pharmacological evaluation of N4,N6-disubstituted pyrimidine-4,6-diamine derivatives as potent EGFR inhibitors in non-small cell lung cancer. Eur. J. Med. Chem. 2018, 157, 1300-1325. [CrossRef] [PubMed]

8. Ma, T.; Zou, F.; Pusch, S.; Yang, L.; Zhu, Q.; Xu, Y.; Gu, Y.; von Deimling, A.; Zha, X. Design, synthesis and biological activity of 3-pyrazine-2-yl-oxazolidin-2-ones as novel, potent and selective inhibitors of mutant isocitrate dehydrogenase 1. Biorg. Med. Chem. 2017, 25, 6379-6387. [CrossRef]

9. Yuan, X.; Wu, H.; Bu, H.; Zheng, P.; Zhou, J.; Zhang, H. Design, synthesis and biological evaluation of pyridone-aminal derivatives as MNK1/2 inhibitors. Biorg. Med. Chem. 2019, 27, 1211-1225. [CrossRef]

10. Niculescu-Duvaz, I.; Roman, E.; Whittaker, S.R.; Friedlos, F.; Kirk, R.; Scanlon, I.J.; Davies, L.C.; Niculescu-Duvaz, D.; Marais, R.; Springer, C.J. Novel Inhibitors of the v-raf Murine Sarcoma Viral Oncogene Homologue B1 (BRAF) Based on a 2,6-Disubstituted Pyrazine Scaffold. J. Med. Chem. 2008, 51, 3261-3274. [CrossRef]

11. Bregman, H.; Nguyen, H.N.; Feric, E.; Ligutti, J.; Liu, D.; McDermott, J.S.; Wilenkin, B.; Zou, A.; Huang, L.; Li, X.; et al. The discovery of aminopyrazines as novel, potent Nav1.7 antagonists: Hit-to-lead identification and SAR. Bioorg. Med. Chem. Lett. 2012, 22, 2033-2042. [CrossRef]

12. Verheij, M.H.P.; Thompson, A.J.; van Muijlwijk-Koezen, J.E.; Lummis, S.C.R.; Leurs, R.; de Esch, I.J.P. Design, Synthesis, and Structure-Activity Relationships of Highly Potent 5-HT3 Receptor Ligands. J. Med. Chem. 2012, 55, 8603-8614. [CrossRef]

13. Wanka, L.; Iqbal, K.; Schreiner, P.R. The Lipophilic Bullet Hits the Targets: Medicinal Chemistry of Adamantane Derivatives. Chem. Rev. 2013, 113, 3516-3604. [CrossRef]

14. Gilligan, B.S.; Veale, J.; Wodak, J. Amantadine hydrochloride in the treatment of Parkinson's disease. Med. J. Aust. 1970, 2, 634-637. [CrossRef]

15. Hunter, K.R.; Stern, G.M.; Laurence, D.R.; Armitage, P. Amantadine in Parkinsonism. Lancet 1970, 295, 1127-1129. [CrossRef]

16. Da Settimo, A.; Marini, A.M.; Primofiore, G.; Da Settimo, F. Synthesis and evaluation of aminoadamantane derivatives for in vitro anti-HIV and antitumor activities. Farmaco 1995, 50, 321-326.

17. Danilenko, G.I.; Rybalko, S.L.; Maksimov, Y.N.; Baklan, V.F.; Guzhova, S.V. Adamantane-1- and norbornane-2-carboxylic acid hydrazides as HIV inhibitors. Pharm. Chem. J. 2000, 34, 23-24. [CrossRef]

18. Chayrov, R.; Parisis, N.A.; Chatziathanasiadou, M.V.; Vrontaki, E.; Moschovou, K.; Melagraki, G.; Sbirkova-Dimitrova, H.; Shivachev, B.; Schmidtke, M.; Mitrev, Y.; et al. Synthetic Analogues of Aminoadamantane as Influenza Viral Inhibitors-In Vitro, in Silico and QSAR Studies. Molecules 2020, 25, 3989. [CrossRef]

19. Grillaud, M.; Bianco, A. Multifunctional adamantane derivatives as new scaffolds for the multipresentation of bioactive peptides. J. Pept. Sci. 2015, 21, 330-345. [CrossRef]

20. Avdyunina, N.I.; Morqzov, I.S.; Bol'shakova, R.F.; Militareva, N.A.; Klimova, N.V.; Bykov, N.P.; Pyatin, B.M.; Khranilov, A.A.; Dvalishvili, É.G. Synthesis and pharmacological properties of benzimidazoline-3-acetic acid n-adamantylamides. Pharm. Chem. J. 1988, 22, 543-546. [CrossRef]

21. Baxter, A.; Bent, J.; Bowers, K.; Braddock, M.; Brough, S.; Fagura, M.; Lawson, M.; McInally, T.; Mortimore, M.; Robertson, M.; et al. Hit-to-Lead studies: The discovery of potent adamantane amide P2X7 receptor antagonists. Bioorg. Med. Chem. Lett. 2003, 13, 4047-4050. [CrossRef]

22. Sorensen, B.; Rohde, J.; Wang, J.; Fung, S.; Monzon, K.; Chiou, W.; Pan, L.; Deng, X.; Stolarik, D.; Frevert, E.U.; et al. Adamantane 11- $\beta$-HSD-1 inhibitors: Application of an isocyanide multicomponent reaction. Bioorg. Med. Chem. Lett. 2006, 16, 5958-5962. [CrossRef] [PubMed] 
23. Rohde, J.J.; Pliushchev, M.A.; Sorensen, B.K.; Wodka, D.; Shuai, Q.; Wang, J.; Fung, S.; Monzon, K.M.; Chiou, W.J.; Pan, L.; et al. Discovery and Metabolic Stabilization of Potent and Selective 2-Amino-N-(adamant-2-yl) Acetamide 11 $\beta$-Hydroxysteroid Dehydrogenase Type 1 Inhibitors. J. Med. Chem. 2007, 50, 149-164. [CrossRef] [PubMed]

24. Ryu, J.H.; Kim, S.; Han, H.Y.; Son, H.J.; Lee, H.J.; Shin, Y.A.; Kim, J.-S.; Park, H.-G. Synthesis and biological evaluation of picolinamides as potent inhibitors of $11 \beta$-hydroxysteroid dehydrogenase type 1 (11ß-HSD1). Bioorg. Med. Chem. Lett. 2015, 25, 695-700. [CrossRef]

25. Collins, K.C.; Janda, K.D. Investigating Hapten Clustering as a Strategy to Enhance Vaccines against Drugs of Abuse. Bioconjugate Chem. 2014, 25, 593-600. [CrossRef]

26. Stankova, I.; Chuchkov, K.; Chayrov, R.; Mukova, L.; Galabov, A.; Marinkova, D.; Danalev, D. Adamantane Derivatives Containing Thiazole Moiety: Synthesis, Antiviral and Antibacterial Activity. Int. J. Pept. Res. Ther. 2020, 26, 1781-1787. [CrossRef]

27. Samson, D.; Daltrozzo, E. Synthesis of Diheteroarylamine Ligands by Palladium-Catalyzed Mono- and Diamination of Dichloroheteroarenes with Heteroarenamines. Helv. Chim. Acta 2011, 94, 46-60. [CrossRef]

28. Wang, A.; Zhang, H.; Biehl, E.R. Preparation of N1-alkyl- and N1,N1-dialkylisoquinoline-1,3-diamines and 1-alkyl- and 1phenylisoquinolin-3-amines from the reaction of $\alpha$-cyano- o-tolunitrile with lithium amides, alkyllithiums, and phenyllithium. Heterocycles 2000, 53, 291-300. [CrossRef]

29. Balog, J.; Riedl, Z.; Hajós, G.; Miskolczy, Z.; Biczók, L. New fluorescent isoquinoline derivatives. Tetrahedron Lett. 2011, 52, 5264-5266. [CrossRef]

30. Dubovtsev, A.Y.; Shcherbakov, N.V.; Dar'in, D.V.; Kukushkin, V.Y. The Dichotomy of Gold-catalyzed Interplay between Cyanamides and Ynamides: Controllable Switch from [2+2+2] to [4+2] Cycloaddition. Adv. Synth. Catal. 2020, 362, 26722682. [CrossRef]

31. Abel, A.S.; Grigorova, O.K.; Averin, A.D.; Maloshitskaya, O.A.; Butov, G.M.; Savelyev, E.N.; Orlinson, B.S.; Novakov, I.A.; Beletskaya, I.P. Amination of chloro-substituted heteroarenes with adamantane-containing amines. Russ. Chem. Bull. 2016, 65, 1820-1828. [CrossRef]

32. Abel, A.S.; Averin, A.D.; Buryak, A.K.; Savelyev, E.N.; Orlinson, B.S.; Novakov, I.A.; Beletskaya, I.P. The Palladium-Catalyzed Heteroarylation of Adamantylalkyl Amines with Dihalogenopyridines: Scope and Limitations. Synthesis 2017, 49, 5067-5080.

33. Abel, A.S.; Averin, A.D.; Maloshitskaya, O.A.; Savelyev, E.N.; Orlinson, B.S.; Novakov, I.A.; Beletskaya, I.P. Palladium-Catalyzed Amination of Dichloroquinolines with Adamantane-Containing Amines. Molecules 2013, 18, 2096-2109. [CrossRef]

34. Abel, A.S.; Zenkov, I.S.; Averin, A.D.; Cheprakov, A.V.; Bessmertnykh-Lemeune, A.G.; Orlinson, B.S.; Beletskaya, I.P. Tuning the Luminescent Properties of Ruthenium(II) Amino-1,10-Phenanthroline Complexes by Varying the Position of the Amino Group on the Heterocycle. ChemPlusChem 2019, 84, 498-503. [CrossRef] [PubMed]

35. Hartwig, J.F.; Shaughnessy, K.H.; Shekhar, S.; Green, R.A. Palladium-catalyzed amination of aryl halides. Org. React. 2019, 100, 853-958.

36. Hooper, M.W.; Utsunomiya, M.; Hartwig, J.F. Scope and Mechanism of Palladium-Catalyzed Amination of Five-Membered Heterocyclic Halides. J. Org. Chem. 2003, 68, 2861-2873. [CrossRef]

37. Shen, Q.; Hartwig, J.F. [(CyPF-tBu)PdCl2]: An Air-Stable, One-Component, Highly Efficient Catalyst for Amination of Heteroaryl and Aryl Halides. Org. Lett. 2008, 10, 4109-4112. [CrossRef]

38. Lyakhovich, M.S.; Murashkina, A.V.; Averin, A.D.; Abel, A.S.; Maloshitskaya, O.A.; Savelyev, E.N.; Orlinson, B.S.; Beletskaya, I.P. Arylation of Adamantanamines: X. Palladium- and Copper-Catalyzed Heteroarylation of Adamantane-Containing Amines with Bromopyridines. Russ. J. Org. Chem. 2019, 55, 737-747. [CrossRef]

39. Averin, A.D.; Ranyuk, E.R.; Golub, S.L.; Buryak, A.K.; Savelyev, E.N.; Orlinson, B.S.; Novakov, I.A.; Beletskaya, I.P. Synthesis of a New Family of Adamantylpyridin-2-amines by Palladium-Catalyzed Amination. Synthesis 2007, 2007, 2215-2221. [CrossRef]

40. Grigorova, O.K.; Averin, A.D.; Abel, A.S.; Maloshitskaya, O.A.; Kovalev, V.V.; Savelev, E.N.; Orlinson, B.S.; Novakov, I.A.; Beletskaya, I.P. Arylation of adamantanamines: IV. Palladium-catalyzed arylation of amines of adamantane series with isomeric chloroquinolines. Russ. J. Org. Chem. 2012, 48, 1391-1406. [CrossRef]

41. Raczyńska, E.D.; Kosińska, W.; Ośmiałowski, B.; Gawinecki, R. Tautomeric Equilibria in Relation to Pi-Electron Delocalization. Chem. Rev. 2005, 105, 3561-3612. [CrossRef]

42. Raczyńska, E.D.; Kolczyńska, K.; Stępniewski, T.M. Consequences of one-electron oxidation and one-electron reduction for 4-aminopyrimidine-DFT studies. J. Mol. Model. 2012, 18, 3523-3533. [CrossRef]

43. Plakhotnik, V.M.; Kovtun, V.Y.; Krasutskii, P.A.; Novikova, M.I.; Prokhorov, A.B. Derivatives of Adamantane. I. 2Hydroxyethylamino Derivatives of Adamantane. J. Org. Chem. USSR 1981, 17, 1287-1290.

44. Novakov, I.A.; Kulev, I.A.; Radchenko, S.S.; Birznieks, K.A.; Boreko, E.I.; Vladyko, G.V.; Korobchenko, L.V. Synthesis and antiviral activity of the hydrochlorides of alicyclic mono- and diamines. Pharm. Chem. J. 1987, 21, 287-291. [CrossRef]

45. Novakov, I.A.; Orlinson, B.S.; Savel'ev, E.N.; Potaenkova, E.A.; Shilin, A.K. Method of Produging 2-(2-Amino) Alkyladamantanes. Patent number RU2495020C1, 10 October 2013. Available online: https:/ / patents.google.com/patent/RU2495020C1/ru (accessed on 25 March 2021).

46. Joubert, J.; Dyk, S.V.; Green, I.R.; Malan, S.F. Synthesis, evaluation and application of polycyclic fluorescent analogues as N-methyl-d-aspartate receptor and voltage gated calcium channel ligands. Eur. J. Med. Chem. 2011, 46, 5010-5020. [CrossRef]

47. Ukai, T.; Kawazura, H.; Ishii, Y.; Bonnet, J.J.; Ibers, J.A. Chemistry of dibenzylideneacetone-palladium(0) complexes: I. Novel tris(dibenzylideneacetone)dipalladium(solvent) complexes and their reactions with quinones. J. Organomet. Chem. 1974, 65, 253-266. [CrossRef] 